\title{
Neoproterozoic magmatic evolution of the southern Ouaddaï Massif (Chad)
}

\author{
Félix Djerossem ${ }^{1}$, Julien Berger ${ }^{1,}$, Olivier Vanderhaeghe ${ }^{1}$, Moussa Isseini ${ }^{2}$, Jérôme Ganne ${ }^{1}$ and Armin Zeh $^{3}$ \\ ${ }^{1}$ GET-OMP, Université de Toulouse, UPS, CNRS, IRD, CNES, 14, avenue E. Belin, 31400 Toulouse, France \\ ${ }^{2}$ Université de N'Djamena, Département de Géologie, B.P. 1027, N'Djamena, Tchad \\ ${ }^{3}$ KIT-Karlsruher Institut für Technologie, Campus Süd, Institut für Angewandte Geowissenschaften, Abteilung Mineralogie und \\ Petrologie, Kaiserstr. 12, D76131 Karlsruhe, Germany
}

Received: 9 January 2020 / Accepted: 20 July 2020

\begin{abstract}
This paper presents new petrological, geochemical, isotopic $(\mathrm{Nd})$ and geochronological data on magmatic rocks from the poorly known southern Ouaddaï massif, located at the southern edge of the socalled Saharan metacraton. This area is made of greenschist to amphibolite facies metasediments intruded by large pre- to syn-tectonic batholiths of leucogranites and an association of monzonite, granodiorite and biotite granite forming a late tectonic high-K calc-alkaline suite. $\mathrm{U}-\mathrm{Pb}$ zircon dating yields ages of $635 \pm 3 \mathrm{Ma}$ and $613 \pm 8 \mathrm{Ma}$ on a peraluminous biotite-leucogranite (containing numerous inherited Archean and Paleoproterozoic zircon cores) and a muscovite-leucogranite, respectively. Geochemical fingerprints are very similar to some evolved Himalayan leucogranites suggesting their parental magmas were formed after muscovite and biotite dehydration melting of metasedimentary rocks. A biotite-granite sample belonging to the late tectonic high-K to shoshonitic suite contains zircon rims that yield an age of $540 \pm 5 \mathrm{Ma}$ with concordant inherited cores crystallized around $1050 \mathrm{Ma}$. Given the high-Mg\# (59) andesitic composition of the intermediate pyroxene-monzonite, the very similar trace-element signature between the different rock types and the unradiogenic isotopic signature for $\mathrm{Nd}$, the late-kinematic high-K to shoshonitic rocks formed after melting of the enriched mantle and further differentiation in the crust. These data indicate that the southern Ouaddaï was part of the Pan-African belt. It is proposed that it represents a continental back-arc basin characterized by a high-geothermal gradient during Early Ediacaran leading to anatexis of middle to lower crustal levels. After tectonic inversion during the main Pan-African phase, late kinematic high-K to shoshonitic plutons emplaced during the final post-collisional stage.
\end{abstract}

Keywords: Central Africa Orogenic Belt / Pan-African / Saharan Metacraton / peraluminous granites / shoshonitic magmatism

\begin{abstract}
Résumé - Evolution magmatique néoprotérozoïque du sud Ouaddaï (Tchad). Cette étude apporte les premières données pétrologiques, géochimiques et isotopiques sur les roches magmatiques du Ouaddaï au Tchad, massif appartenant à la bordure sud du métacraton saharien. Le Ouaddaï est composé de séries métasédimentaires, comportant des intercalations magmatiques mafiques sous forme d'amphibolite. Ces séries sédimentaires recristallisées dans les conditions du faciès des schistes verts et des amphibolites, sont intrudées par de larges batholithes leucogranitiques peralumineux et par des petits plutons de monzonite à pyroxène, granodiorite à hornblende et granite à biotite formant une série calco-alcaline fortement potassique à shoshonitique. L'âge des granites peralumineux a été contraint par datation U-Pb sur zircon qui donne $635 \pm 3$ Ma pour un leucogranite à biotite et $613 \pm 8$ Ma pour un leucogranite à muscovite et grenat. Le granite le plus vieux contient en outre une série de zircons hérités d'âge Archéen à Paléoprotérozoïque. Les caractéristiques pétrologiques des leucogranites du Ouaddaï sont semblables à celles des leucogranites himalayens, leur origine est compatible avec une formation des magmas parentaux par fusiondéshydratation de métasédiments. L'âge de la série métalumineuse, calco-alcaline et fortement potassique à shoshonitique a été déterminé à $540 \pm 5 \mathrm{Ma}$ par datation U-Pb sur zircons d'un granite à biotite. Cet échantillon contient de plus des cœurs de zircon hérités mésoprotérozoïques $(\sim 1.05 \mathrm{Ga})$ marquant un événement magmatique encore peu reconnu en Afrique centrale. Le Mg\# élevé (59) de la monzonite couplé
\end{abstract}

*Corresponding author: julien. berger@get.omp.eu 
à la signature fortement potassique à shoshonitique de la série incite à interpréter ces roches comme résultant de la différentiation de magmas basiques à intermédiaires issus de la fusion partielle d'un manteau enrichi. Ces données pionnières montrent que le Ouaddaï appartient à la chaîne panafricaine d'Afrique centrale. Il formait un bassin d'arrière arc continental caractérisé par un gradient géothermique élevé induisant la fusion partielle de la croûte moyenne à inférieure vers 635-612 Ma. Après l'inversion tectonique de ce bassin, la phase finale de l'orogenèse panafricaine est marquée, au Ouaddaï et à l'échelle de la ceinture orogénique d'Afrique centrale, par la mise en place de plutons fortement potassiques à shoshonitiques typiques des séries post-collisionnelles.

Mots clés : Ceinture Orogénique d'Afrique Centrale / Panafricain / Métacraton du Sahara / granites peralumineux / magmatisme shoshonitique

\section{Introduction}

The Precambrian geology of central Africa can be described as Archean/Paleoproterozoic cratons assembled during the PanAfrican orogeny. In particular, the Central Africa Orogenic Belt (CAfOB, Fig. 1) is delimited to the west and to the south by the West Africa and Congo cratons, respectively, which comprise an Archean cratonic nucleus and remnants of Paleoproterozoic Eburnean orogenic belts that have not been reworked during the Pan-African orogeny. In contrast, the northeastern boundary of the CAfOB is more enigmatic. In this region, the basement pointing from beneath the Phanerozoic sedimentary covers in Sudan, Chad and Lybia has been described successively as the Nile craton (Rocci, 1965), the East Sahara craton (Bertrand and Caby, 1978), the Ghost Saharan craton (Black and Liégeois, 1993), the Saharan metacraton (Abdelsalam et al., 2002), or as a large Neoproterozoic belt involving no craton but characterized by the presence of $1.0 \mathrm{Ga}$ basement rocks in Sudan (de Wit and Linol, 2015).

The Ouaddaï massif in eastern Chad is one of the least known areas of Africa regarding its geological evolution. Penaye et al. (2006) consider it consists of Paleoproterozoic basement rocks while Abdelsalam et al. (2002), Begg et al. (2009) and Liégeois et al. (2013) consider that it corresponds to the reworked southeastern margin of the enigmatic Sahara metacraton made of Archean and Paleoproterozoic preexisting crust. Toteu et al. (2004) propose it is a Neoproterozoic juvenile crustal segment locally contaminated by Paleoproterozoic crust. All these assumptions are made without any geological or geochronological data, except for $\mathrm{Nd}$ model ages on crustal xenoliths from Cenozoic basaltic deposits in the neighboring Darfur massif in Sudan yielding 790 to $2800 \mathrm{Ma}$ (Abdelsalam et al., 2002).

In this study, we present new field, petrological and geochronological data on magmatic rocks (Tab. 1) from the southern Ouaddaï massif (extending to the Darfur massif in Sudan), where Precambrian rocks are unconformably covered by Phanerozoïc sediments. These data are used to constrain the ages, compositions and sources of the plutonic rocks, and to discuss the geotectonic significance of the Ouaddaï massif within the puzzle of cratonic margins and Pan-African orogenic belts characterizing the geology of central Africa.

\section{Geological setting}

The Ouaddaï massif, cropping out in southeastern Chad, is located between the Saharan metacraton to the north and the Congo craton to the south (Figs. 1 and 2a). It represents the easternmost exposure of the Pan-African Central Africa Orogenic Belt (CAfOB, Fig. 1; Bessoles and Trompette, 1980; Toteu et al., 2004). Geological mapping carried out by Gsell and Sonnet (1960); Wolff (1964) and Van Osta (1991) led to the distinction of a northern Ouaddaï massif mainly made of granitoïds and migmatites, and a southern Ouaddaï massif dominated by metasedimentary rocks. Our field investigations in southern Ouaddaï document intensely deformed series of muscovite-bearing quartzite, muscovitebiotite metapelites intercalated by rare marbles and calcsilicate gneisses (Fig. 2b). These rocks recorded greenschist facies conditions grading toward amphibolite facies as shown by the uncommon occurrence of garnet and sillimanite defining the main regional foliation. Rare coarse grained amphibolite alternate with the metasediments and correspond to the oldest exposed magmatic rocks of the area (Fig. 2b). Preliminary $\mathrm{U}-\mathrm{Pb}$ dating of detrital zircons in quartzites yielded maximum depositional age of $1 \mathrm{Ga}$ (Djerossem, 2018) proving that sedimentation occurred during the Neoproterozoic. The main structural foliation in the metasediments dominantly strikes N30-40 and is associated with superimposed isoclinal folds refolded at the regional scale by open vertical folds with axial planes subparallel to the main foliation. The metasedimentary series is intruded by a variety of plutons comprising leucogranite batholiths affected by, and wrapped into the main foliation of the metasediments as well as smaller plutons of monzonite, granodiorite and granite that cut across the main foliation and display a magmatic fabric. The latter occasionally form very small apophysis intruding the large peraluminous batholiths. Accordingly, plutons of intermediate to felsic composition of the southern Ouaddai are subdivided in two groups: (1) pre- to syn-tectonic large batholiths of muscovite and biotite leucogranites; (2) late to post-tectonic small plutons of metaluminous pyroxene monzonite, biotite- and hornblende-bearing granodiorite and biotite granite (Fig. 1b).

$\mathrm{U}-\mathrm{Pb}$ dating of zircons in the neighboring areas in Cameroon and Chad; Fig. 1) indicate a protracted magmatic activity characterized by emplacement of plutons with dominant calc-alkaline signature associated with minor tholeiitic and peraluminous magmas from $750 \mathrm{Ma}$ to $600 \mathrm{Ma}$ ending with the emplacement of post-collisional high-K calc-alkaline to shoshonitic igneous rocks with minor anatectic and A-type granites at about 590-545 Ma (Toteu et al., 2004; Shellnutt et al., 2019). 


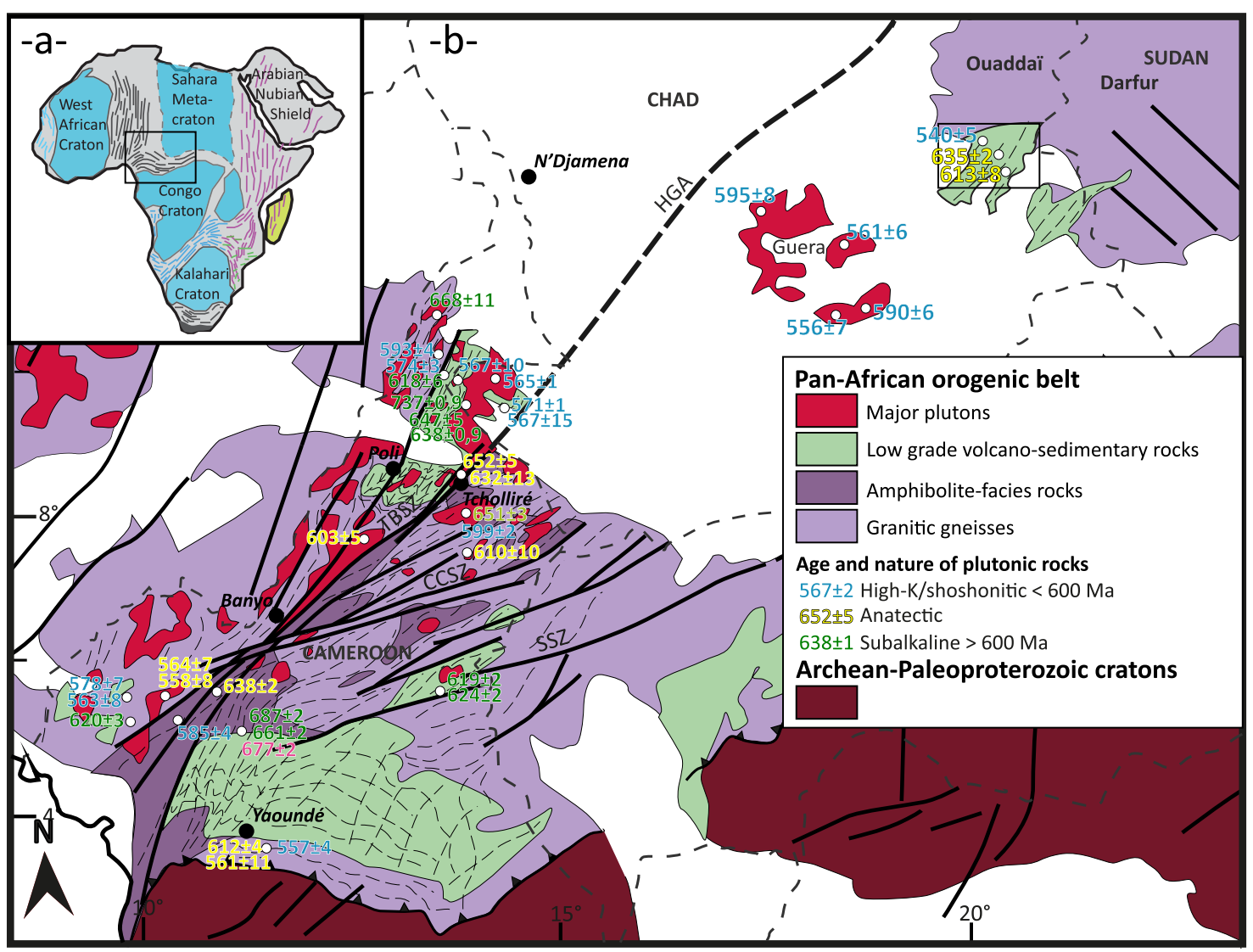

Fig. 1. (a) Position of cratons within Africa. (b) Schematic geological map of the Central Africa fold belt adapted from Milesi et al. (2004); Toteu et al. $(2001,2004)$ and Saha Fouotsa et al. (2019). Age of representative plutonic rocks are indicated as follow: pre- to syn-orogenic subalkaline rocks ( $>600 \mathrm{Ma})$, anatectic peraluminous granites and post collisional high-K calc alkaline rocks $(<600 \mathrm{Ma})$. Inset in the Ouaddaï massif shows the location of map drawn in Figure 2. References are cited in the text.

\section{Analytical methods}

Rocks samples were sawed into chips for thin section preparation and trimmed to small blocks for geochemical investigations. About 200 to $500 \mathrm{~g}$ of each sample was crushed into a steel jaw crusher and then pulverized with an agate ball mill. Powders were digested using an alkali fusion procedure where the powder was mixed to lithium metaborate and melted to produce a glass pellet. The pellet was digested into diluted nitric acid before analyses. Analyses and digestions were made at the "Service d'Analyse des Roches et Minéraux" (SARM, CRPG, France); major elements were dosed by ICP-OES while trace-elements were determined by ICP-MS following the procedure detailed in Carignan et al. (2001). The isotopic composition of $\mathrm{Nd}$ was also measured at the SARM by MC-ICP-MS following the protocol exposed by Luais et al. (1997).

For U-Pb zircon dating, about 1 to $2 \mathrm{~kg}$ of sample was crushed and then sieved to keep the $100-500 \mu \mathrm{m}$ fraction. The pulp was rinsed with water to wash out the fine particles and dried overnight. Quartz and feldspar were first separated using bromoform, and ferromagnetic and paramagnetic minerals were removed using a Frantz isodynamic separator. Apatite was sorted from zircons and other dense minerals in di-iodomethane heavy liquid. Final selection of zircon grains was made by hand-picking before mounting in epoxy resin. Prior to $\mathrm{U}-\mathrm{Pb}$ dating the internal structure of zircon grains was investigated by cathodoluminescence (CL) and back scattered electron (BSE) imaging using a JEOL JSM-6490 scanning electron microscope (SEM) coupled with a Gatan Mini CL at the Goethe University (Frankfurt, Germany). U-Pb dating was carried out by laser ablation - sector field - inductively coupled mass spectrometry (LA-ICP-MS) also at the Goethe University (Frankfurt, Germany) following the method described by Zeh and Gerdes (2012). Laser spots were $30 \mu \mathrm{m}$ in diameter and approximately $20 \mu \mathrm{m}$ in depth. U and $\mathrm{Pb}$ content and $\mathrm{Th} / \mathrm{U}$ ratio were calculated relative to $\mathrm{GJ}-1$ reference zircon. Isotopic data were corrected for background, intra-run elemental fractionation, and common $\mathrm{Pb}$ using an inhouse EXCEL ${ }^{\circledR}$ spreadsheet (for details see Gerdes and Zeh, 2009) that incorporates the Pb evolutionary model of Stacey and Kramers (1975). All data U-Pb age data were corrected by standard bracketing relative to the zircon standard GJ-1 (primary standard; Jackson et al., 2004), which yielded after background, daily drift, and common $\mathrm{Pb}$ correction a Concordia age of $603.6 \pm 1.6 \mathrm{Ma}\left(2 \mathrm{SD} ; n=28 ; \mathrm{MSWD}_{\mathrm{C}+\mathrm{E}}=0.46, \operatorname{Prob}_{\mathrm{C}+\mathrm{E}}=0.99\right.$; $\mathrm{SD}-$ standard deviation; $\mathrm{C}+\mathrm{E}-$ concordance and equivalence). 


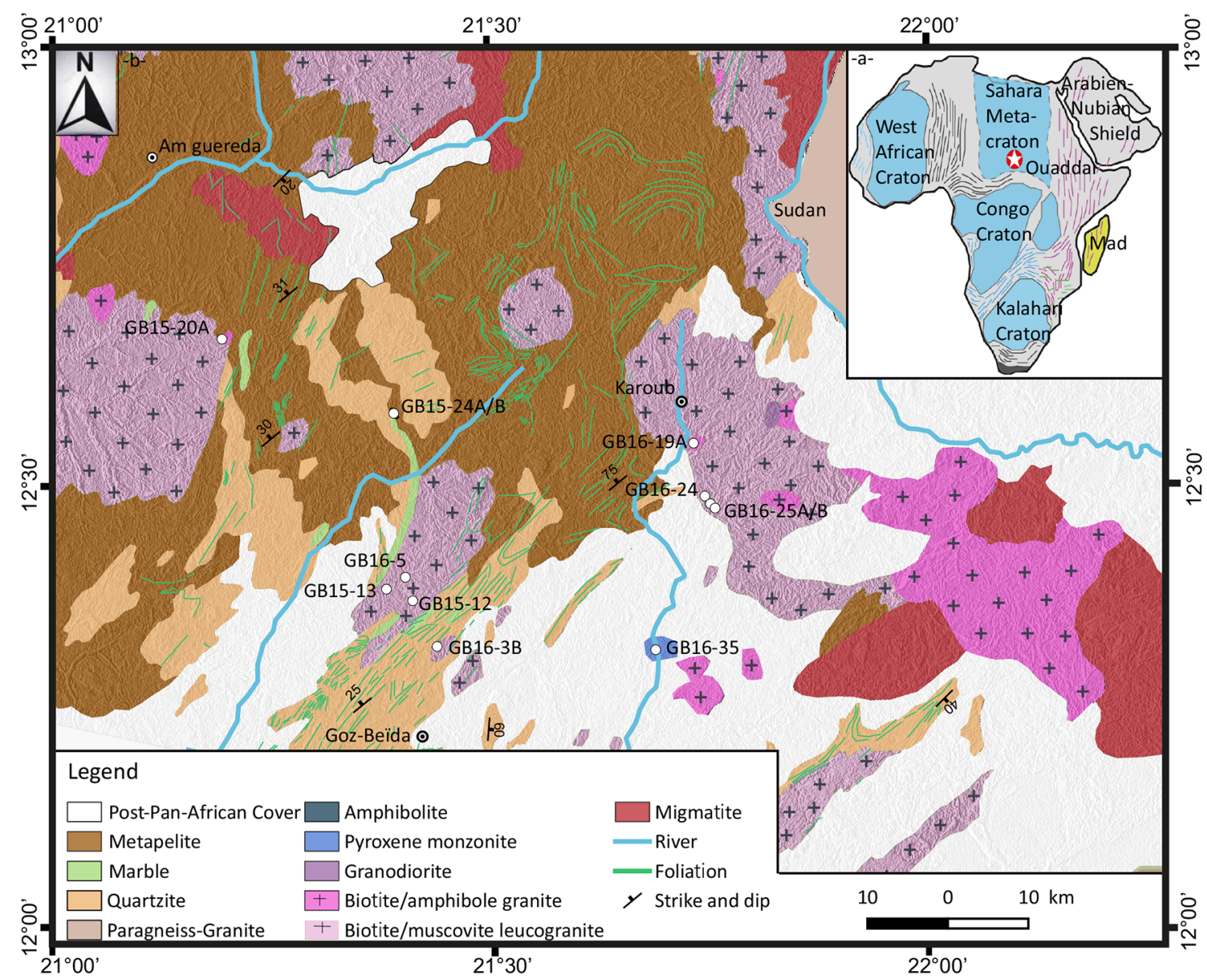

Fig. 2. Geological map of Ouaddaï massif (modified from Gsell and Sonnet, 1960): the study area is located in the southern part of Ouaddaï.

The accuracy of the zircon $\mathrm{U}-\mathrm{Pb}$ isotope method was verified by the analyses of reference zircons Plešovice and OG-1 (secondary standards), which yielded Concordant ages of $339.0 \pm 1.3 \mathrm{Ma}$ $\left(\mathrm{MSWD}_{\mathrm{C}+\mathrm{E}}=0.83, \quad \operatorname{Prob}_{\mathrm{C}+\mathrm{E}}=0.71, \quad n=14\right), \quad$ and $3466.8 \pm 6.4 \mathrm{Ma}\left(\mathrm{MSWD}_{\mathrm{C}+\mathrm{E}}=1.1, \operatorname{Prob}_{\mathrm{C}+\mathrm{E}}=0.31, n=11\right)$, in agreement with published data (Sláma et al., 2008; Stern et al., 2009). The results of U-Pb dating and standard measurements are shown in Tables 2-4 and in Figures 5a-5f.

\section{Petrography of (meta-)magmatic rocks from southern Ouaddaï massif}

\subsection{Amphibolites}

Amphibolites occur as small isolated bodies (Fig. 2b). Contacts with surrounding metasedimentary rocks are nowhere exposed but the shape of these bodies underlines the regional foliation. The amphibolites consist of amphibole, plagioclase, titanite, epidote and minor quartz. They commonly show a grano-poikiloblastic texture and the preferred orientation of amphibole and plagioclase defines a pervasive schistosity (Figs. 3a and 3b). In the investigated samples, two generations of amphibole are identified. The first generation comprises coarse grained hornblende crystals, and the second generation is made of fibers of actinolite associated to plagioclase. The latter occurs either as very fine xenomorphic crystals in the matrix or forms inclusions in large hornblende crystals. Titanite, epidote and quartz are present as small crystals within the matrix.

\subsection{Leucogranites}

Biotite-leucogranite (sample GB16-5, GB16-25A, GB16-25B) forms large plutons wrapped in the regional foliation. It displays a heterogranular texture and consists of Kfeldspar, quartz, plagioclase and biotite (Figs. 3c and 3d). Secondary minerals are represented by epidote and oxides. Potassium feldspar $(\sim 50 \mathrm{vol} . \%)$ is perthitic and contains inclusions of biotite and quartz. Plagioclase $(\sim 20 \mathrm{vol} . \%)$ is subhedral while biotite $(<5 \mathrm{vol} . \%)$ is present interstitially between $\mathrm{K}$-feldspar and quartz grains and is locally deformed within shear bands (Fig. 3c). Quartz $(\sim 25$ vol.\%) forms elongated kinked grains surrounded by small polygonal neoblasts (Fig. 3d).

Muscovite leucogranite (sample GB16-3B, GB15-12) forms elongated bodies subconcordant to the regional foliation (Fig. 3e). They have a medium grained texture and are composed of K-feldspar, plagioclase, quartz, and muscovite (Fig. 3f). Potassic feldspar $(\sim 40$ vol. $\%)$ is subhedral to anhedral and contains muscovite, plagioclase and quartz inclusions. Quartz (30 vol.\%) is anhedral and shows microstructures indicative of dynamic recrystallization such as a rolling extinction and small polygonal subgrains along grain 
Table 1. Lithology and coordinates of sample used in this study.

\begin{tabular}{lllll}
\hline Samples & X UTM zone 34 & Y UTM zone 34 & Lithology & Mineralogy \\
\hline GB15-24A/B & 542180 & 1391120 & Amphibolite & $\mathrm{Hbl}+\mathrm{Pl}+\mathrm{Ttn}+\mathrm{Ep} \pm \mathrm{Qtz}$ \\
GB15-35 & 574723 & 1361758 & Monzonite & $\mathrm{Kfs}+\mathrm{Cpx}+\mathrm{Pl}+\mathrm{Opx}+\mathrm{Hbl}+\mathrm{Bt}$ \\
GB15-13 & 540008 & 1369277 & Granodiorite & $\mathrm{Pl}+\mathrm{Qtz}+\mathrm{Kfs}+\mathrm{Bt}+\mathrm{Ttn}+\mathrm{Ep}$ \\
GB16-19A & 579425 & 1387421 & Biotite granite & $\mathrm{Kfs}+\mathrm{Qtz}+\mathrm{Pl}+\mathrm{Bt}$ \\
GB15-20A & 520842 & 1400343 & Biotite granite & $\mathrm{Kfs}+\mathrm{Qtz}+\mathrm{Pl}+\mathrm{Bt}$ \\
GB16-24 & 581529 & 1379901 & Biotite granite & $\mathrm{Kfs}+\mathrm{Qtz}+\mathrm{Pl}+\mathrm{Bt}$ \\
GB16-5 & 543630 & 1370757 & Biotite leucogranite & $\mathrm{Kfs}+\mathrm{Qtz}+\mathrm{Pl}+\mathrm{Bt}$ \\
GB16-25A/B & 582104 & 1379350 & Biotite leucogranite & $\mathrm{Kfs}+\mathrm{Qtz}+\mathrm{P} 1+\mathrm{Ms}+\mathrm{Grt}+\mathrm{Tur}$ \\
GB16-3B & 547569 & 1362162 & Muscovite leucogranite & $\mathrm{Kfs}+\mathrm{Qtz}+\mathrm{Pl}+\mathrm{Ms}$ \\
GB15-12 & 544540 & 1367840 & Muscovite leucogranite & \\
\hline
\end{tabular}

Table 2. Results of U-Pb dating on the biotite leucogranite (GB16-5).

\begin{tabular}{|c|c|c|c|c|c|c|c|c|c|c|c|c|c|}
\hline Spot & $\begin{array}{l}{ }^{207} \mathrm{~Pb} \\
\text { (cps) }\end{array}$ & $\begin{array}{l}\text { U } \\
\text { (ppm) }\end{array}$ & $\begin{array}{l}\mathrm{Pb} \\
(\mathrm{ppm})\end{array}$ & $\begin{array}{l}\text { Th } \\
\mathrm{U}\end{array}$ & $\begin{array}{l}{ }^{206} \mathrm{Pbc} \\
(\%)\end{array}$ & $\begin{array}{l}{ }^{206} \mathrm{~Pb} \\
{ }^{238} \mathrm{U}\end{array}$ & $\begin{array}{l} \pm 2 \sigma \\
(\%)\end{array}$ & $\begin{array}{l}{ }^{207} \mathrm{~Pb} \\
{ }^{235} \mathrm{U}\end{array}$ & $\begin{array}{l} \pm 2 \sigma \\
(\%)\end{array}$ & $\begin{array}{l}{ }^{207} \mathrm{~Pb} \\
{ }^{206} \mathrm{~Pb}\end{array}$ & $\begin{array}{l} \pm 2 \sigma \\
(\%)\end{array}$ & rho & 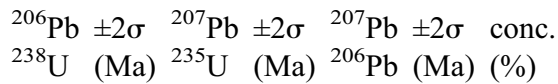 \\
\hline
\end{tabular}

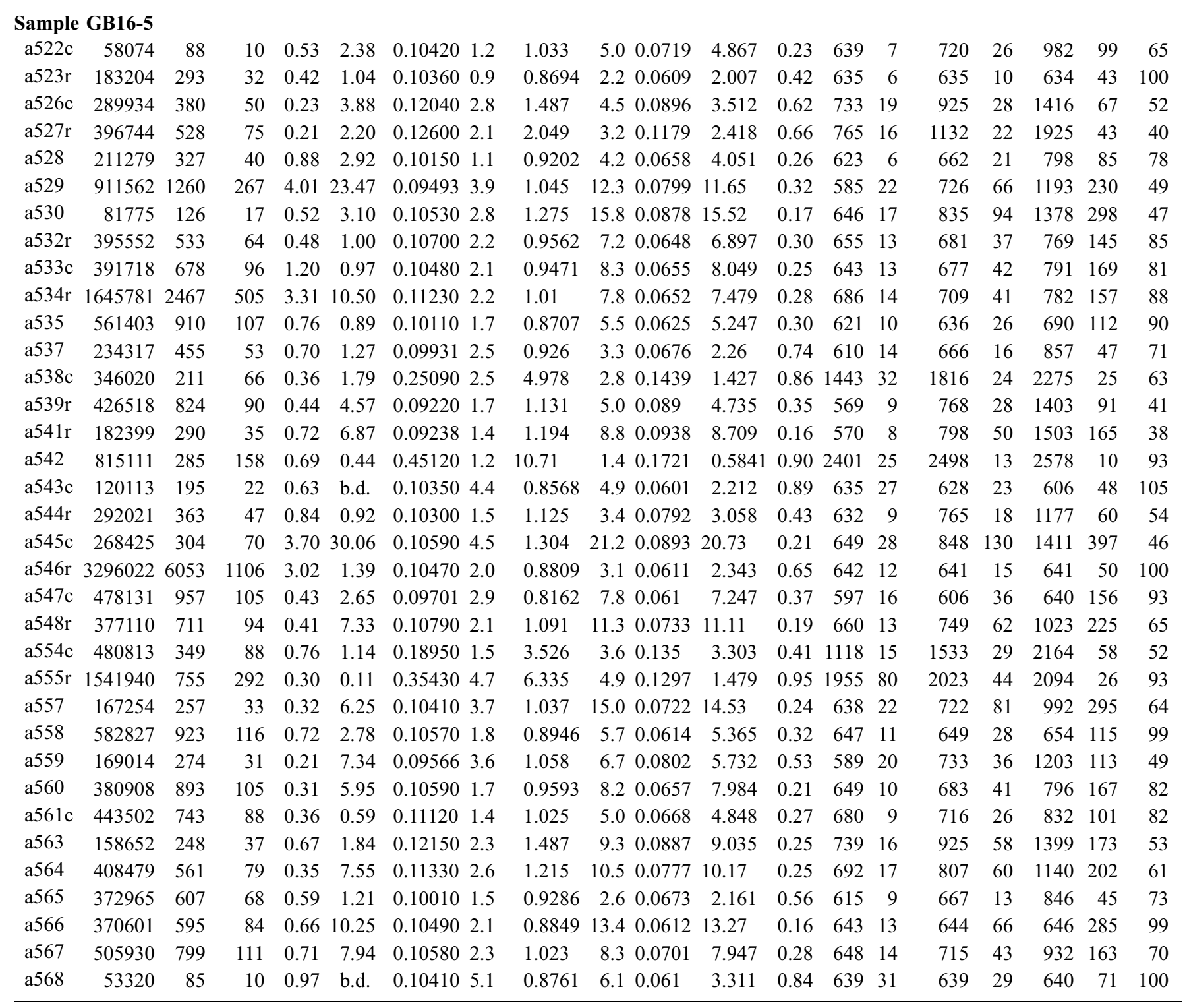


Table 2. (continued).

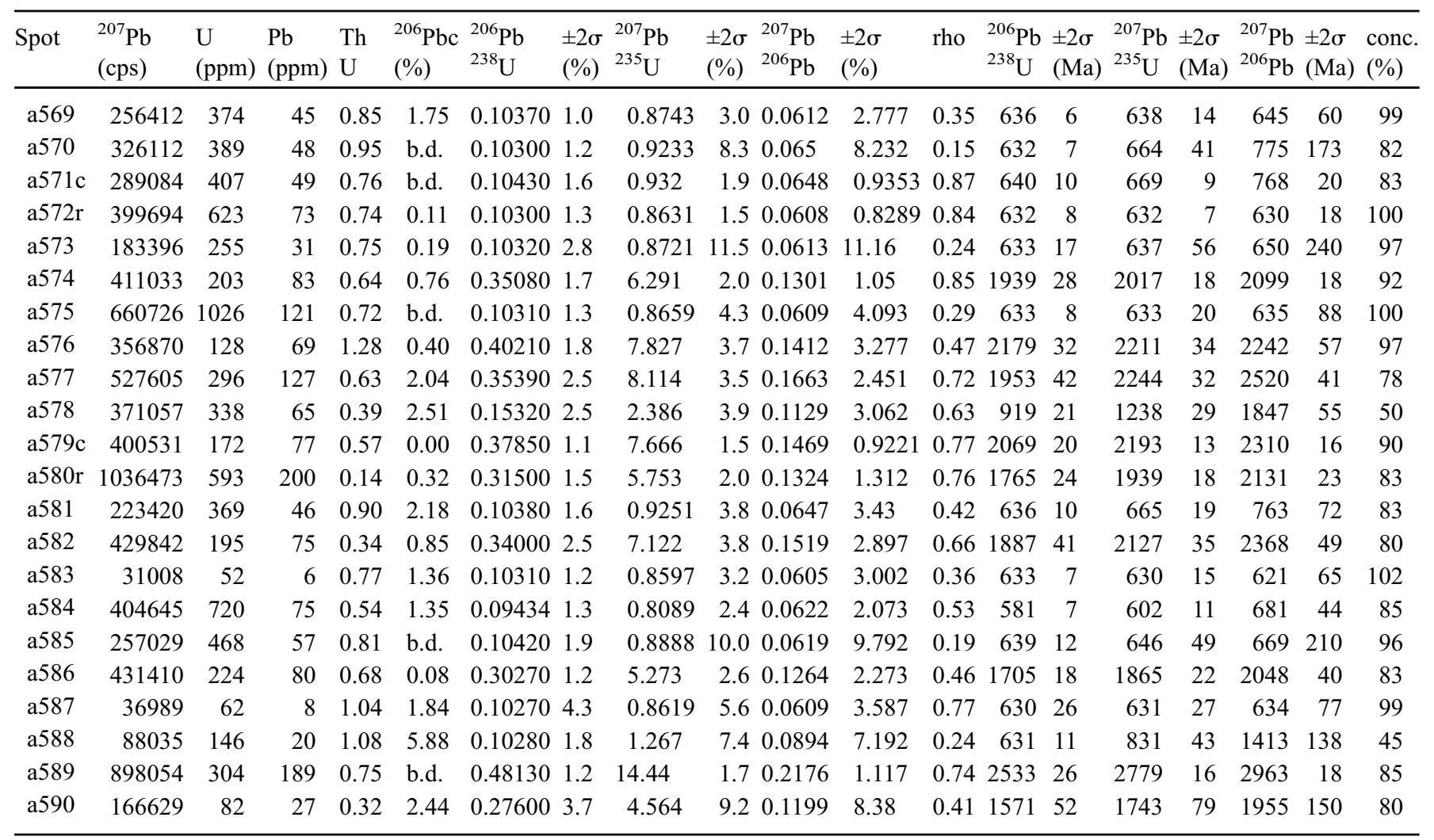

boundaries (Fig. 3g). Plagioclase (20 vol.\%) is subhedral and often altered to sericite. Muscovite $(5 \mathrm{vol} \%)$ is present as tabular grains. Garnet forms rare $(<5 \%)$ euhedral grains containing inclusions of quartz and muscovite. Locally, tourmaline is present as large blue acicular crystals. The preferred orientation of quartz ribbons and of muscovite delineates a solid-state ductile fabric expressed macroscopically as a spaced schistosity.

\subsection{Granodiorite and biotite-granite suite}

Plutons belonging to the granodiorite and biotite-granite suite cut across the structure of the metasediment-amphibolite intercalations but the main foliation is also locally deflected around these plutons (Fig. 2b). These plutonic rocks are dominated by $\mathrm{K}$-feldspar and plagioclase, associated with quartz and biotite, and, in some samples, with clinopyroxene and green amphibole. Accessory minerals include titanite, epidote, zircon, apatite and oxides. Amphibole is restricted to biotite-granite (samples GB16-19A, GB16-24, GB15-20A), whereas granodiorite (sample GB15-13) contains higher amounts of apatite and zircon. Rocks of this suite are characterized mainly by a heterogranular to porphyric texture (Figs. 4a and 4b), locally overprinted by solid-state deformation (Fig. 4c). Localized shear bands are marked by elongated biotite and quartz with bended euhedral plagioclase crystals). Quartz porphyroclasts display kink bands and are surrounded by small polygonal neoblasts.

\subsection{Pyroxene-monzonite}

The pyroxene-monzonite (sample GB16-35) forms a small isolated plutonic body but the contact with host metasedimentary rock is not exposed. It consists of large euhedral crystals of plagioclase and K-feldspar with interstitial domains occupied by clinopyroxene and orthopyroxene (Fig. 4d). Brown amphibole is present along the rim of clinopyroxene and probably crystallized owing to late magmatic reactions between clinopyroxene and melt. Titanite is a very common accessory phase and is accompanied by apatite and zircon. The texture is purely magmatic and there is no evidence for solidstate deformation neither on outcrop scale nor under the microscope.

\section{Geochronology}

$\mathrm{U}-\mathrm{Pb}$ dating was carried out on zircon grains from biotiteleucogranite sample GB16-5, muscovite-leucogranite sample GB15-12 and biotite-granite sample GB15-20A. Images of analyzed zircon grains with the Concordia diagrams are displayed in Figure 5, and the results of $\mathrm{U}-\mathrm{Pb}$ dating presented in Tables 2-4.

Zircon grains in the biotite-leucogranite GB16-5 are euhedral, elongated and prismatic and show a strongly resorbed CL-bright core with an oscillatory zoning, surrounded by an unzoned, CL-dark rim (Fig. 5a). High Th/U ratios $(0.42-1.04$, with two spots at 3.0$)$ of cores and rims 

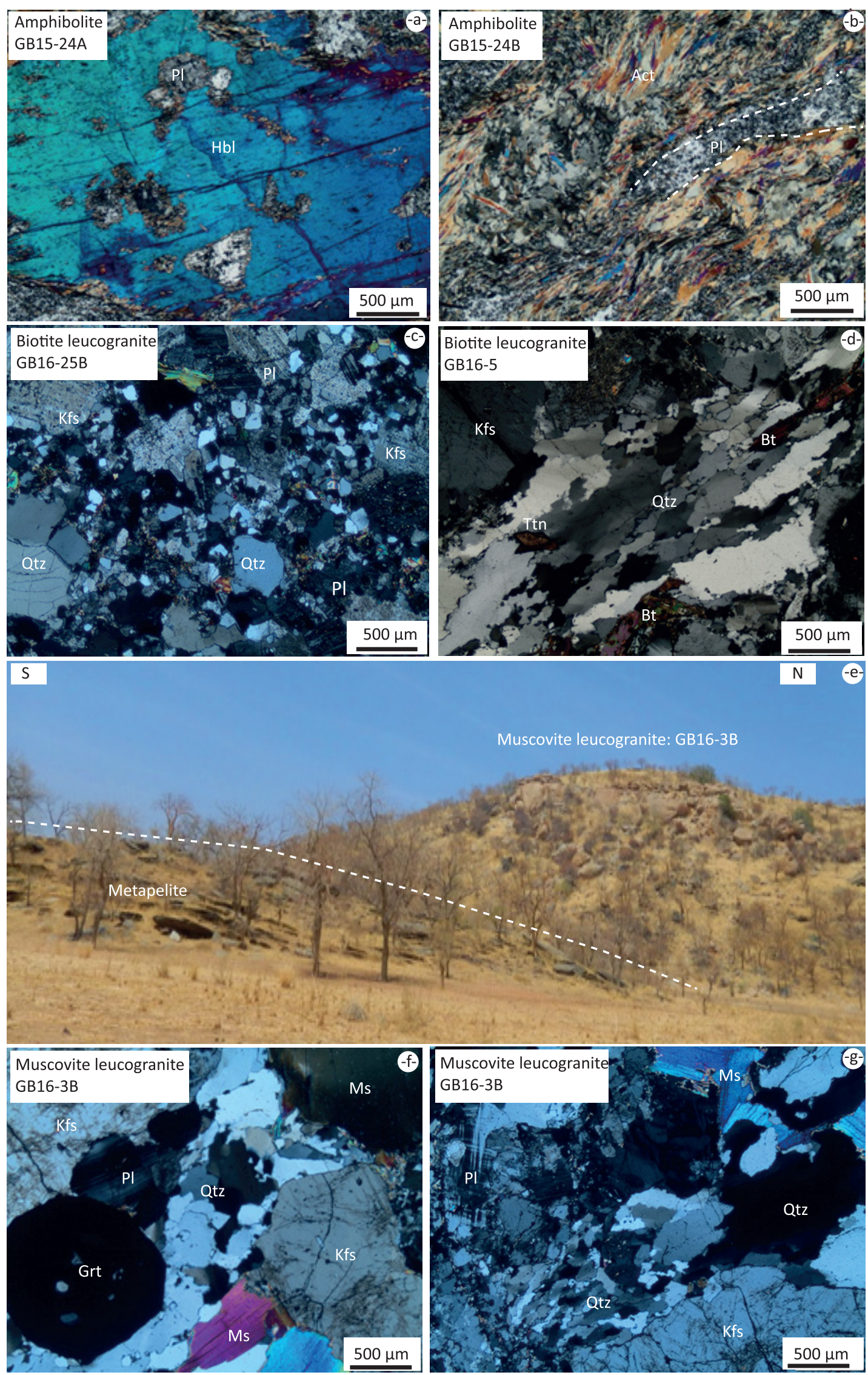

Fig. 3. Macro and micro-photographs of basic to granitic rocks from Southern Ouaddaï. (a and b) amphibolite; (c and d) granodiorite; (e) biotite granite; (f) pyroxene monzonite. 

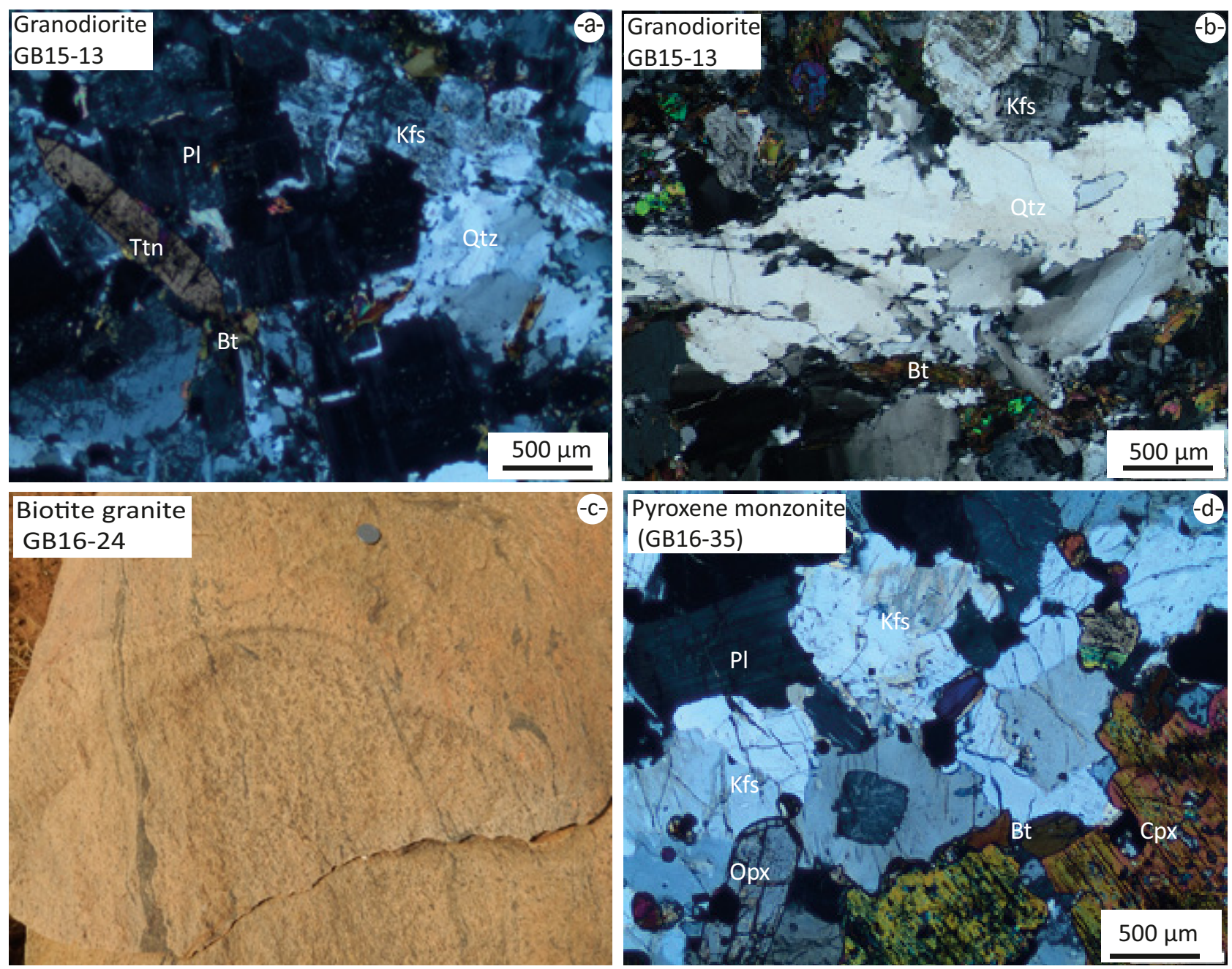

Fig. 4. Macro- and micro-photographs of anatectic leucogranites. (a and b) biotite leucogranite; (c) outcrop of a muscovite leucogranite; (d and e) thin section image of garnet-muscovite leucogranite.

Table 3. Results of U-Pb dating on the muscovite leucogranite (GB15-12).

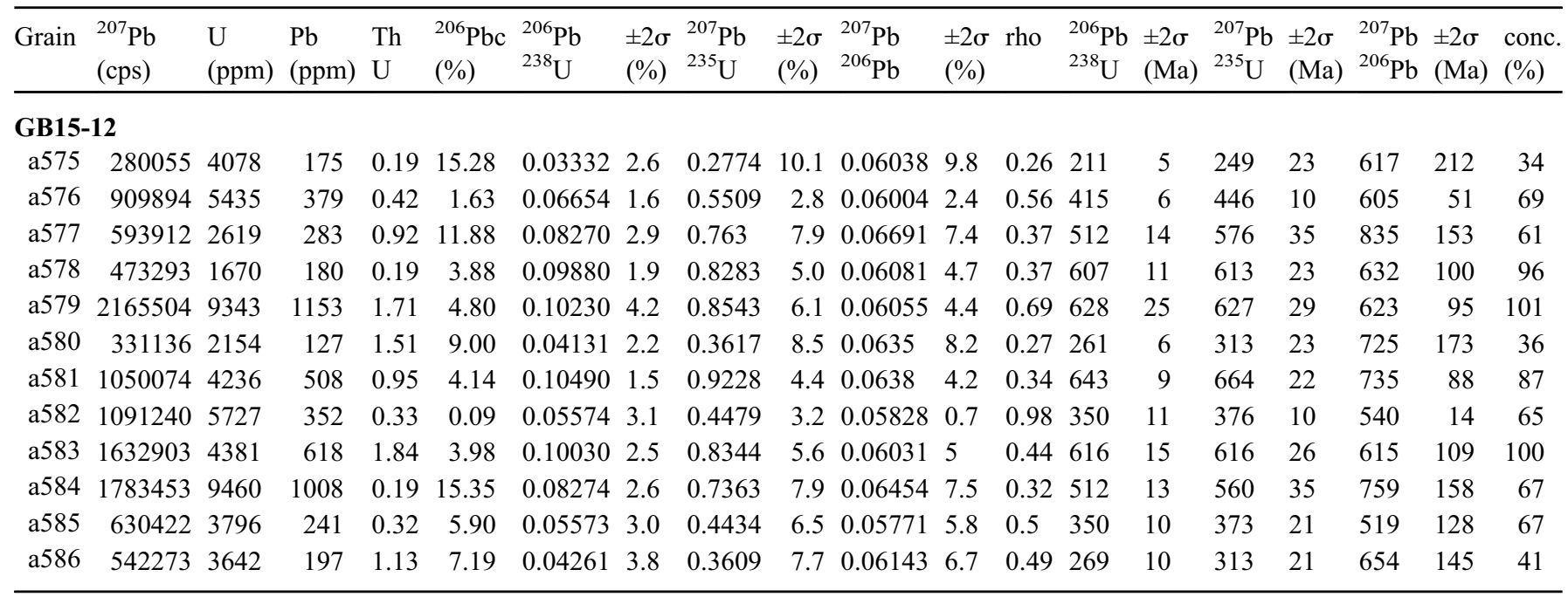



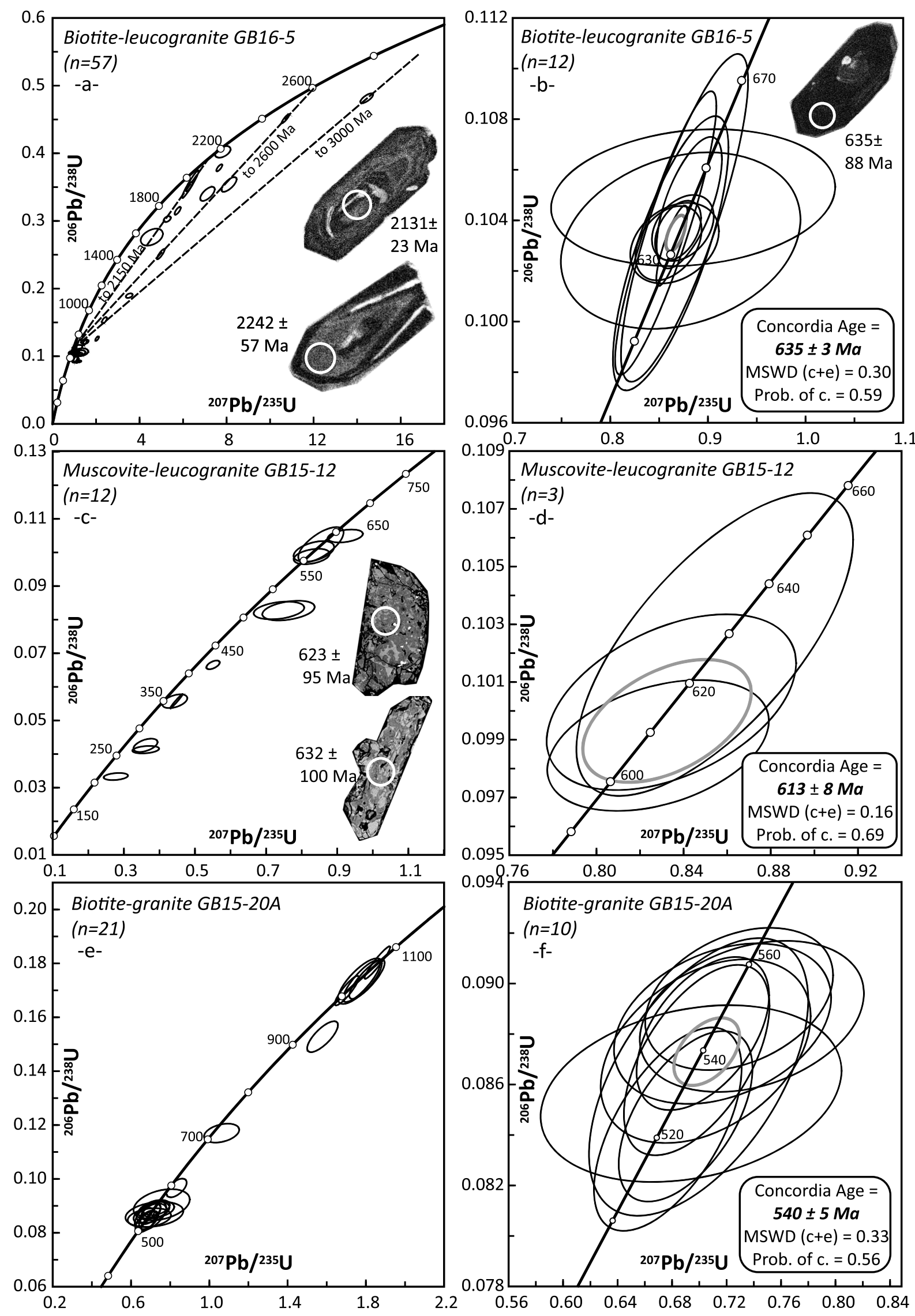

Fig. 5. Zircon U-Pb concordia diagrams for the biotite leucogranite (a, b), muscovite leucogranite (c, d) and biotite granite (e,f) with representative images of zircon textures (spot diameter: $25 \mu \mathrm{m}$ ). Ages indicated near spots are calculated from the ${ }^{207} \mathrm{~Pb} /{ }^{235} \mathrm{U}$ isotopic ratio. 

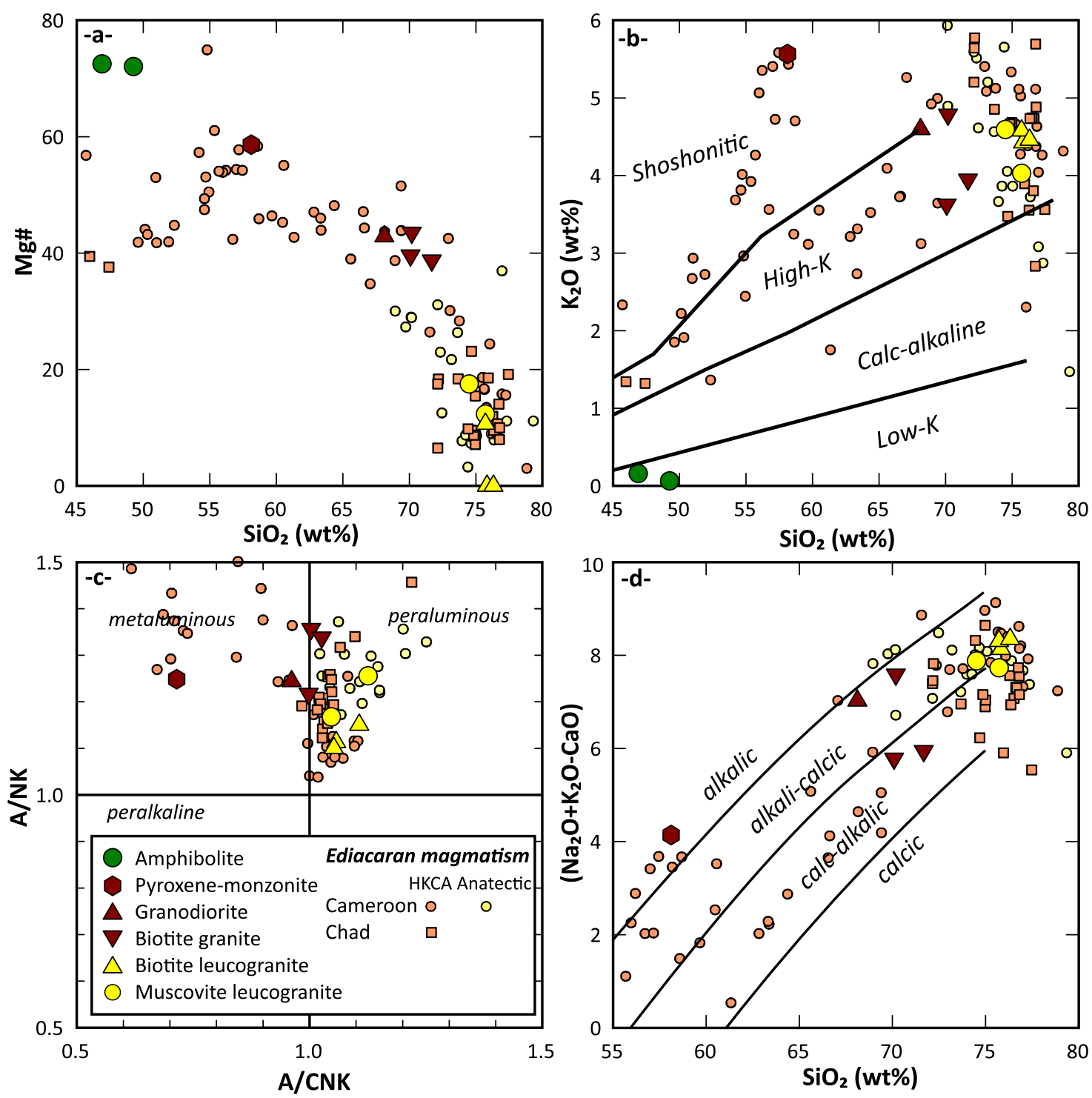

Fig. 6. Major elements classification diagrams for magmatic rocks. (a) $\mathrm{Mg} \#$ vs. $\mathrm{SiO}_{2}$; (b) $\mathrm{K}_{2} \mathrm{O}$ vs. $\mathrm{SiO}_{2}$ (Rickwood, 1989); (c) A/NK vs. A/CNK (Miniar and Piccoli, 1989); (d) MALI classification from Frost et al. (2001). See text for data sources on COAfB occurrences.

suggest a magmatic origin. The age spectrum recovered from these zircon grains reveals a complex history. Zircon cores yield mostly Paleoproterozoic and minor Archean ${ }^{207} \mathrm{~Pb} /{ }^{206} \mathrm{~Pb}$ ages between 3000 and $2048 \mathrm{Ma}$, and twelve rim analyses provide a rather well constrained concordia age of $635 \pm 3 \mathrm{Ma}$ with a MSWD of 0.3 (Figs. 5a and 5b). Some core analyses $(n=8)$ plot on or near to a discordia chord with an upper intercept at $2150 \mathrm{Ma}$, and one core gives a near concordant age at ca. $2200 \mathrm{Ma}$ (analysis a576). The Neoproterozoic age (close to the Cryogenian/Ediacaran boundary) obtained from the rims is interpreted to date the time of granite emplacement.

The muscovite-leucogranite sample GB15-12 contains only a few zircon grains, consistent with the low $\mathrm{Zr}$ content of this sample $(38 \mathrm{ppm})$. The grains are subhedral and stubby except for a few euhedral elongated prismatic grains. The internal texture is patchy, which is typical for re-crystallized zircon grains (Fig. 5c). Th/U ratios between 0.19 and 1.71 suggest re-crystallization of primarily magmatic zircon grains affected by metamictisation due to extremely high $\mathrm{U}$ and $\mathrm{Th}$ contents $(\mathrm{U}=1670-9460 \mathrm{ppm}$; Tab. 3). Generally high common $\mathrm{Pb}$ levels (up to $15.3 \%$ ) suggest infiltration of fluids during re-crystallization (Geisler et al., 2007; Zeh and Gerdes, 2014). Most spot analyses yield discordant ${ }^{206} \mathrm{~Pb} /{ }^{238} \mathrm{U}$ ages younger than $550 \mathrm{Ma}$. Only three analyses yield a concordia age of $613 \pm 8 \mathrm{Ma}$ with a rather low MSWD of 0.16 (Figs. 5c and $5 \mathrm{~d}$ ), which most likely represents a minimum age for magma emplacement. No inherited zircons were identified in this sample.

The biotite granite GB15-20A delivered numerous zircons. $\mathrm{U}-\mathrm{Pb}$ dating yields two age clusters (Figs. 5e and 5f): five ellipses, obtained on zircon with a $\mathrm{Th} / \mathrm{U}$ ranging from 0.03 to 1.37 , are concordant between 1050 and 1100 Ma while 10 spots, with a $\mathrm{Th} / \mathrm{U}$ ranging from 0.12 to 0.97 , characterized by a concordance above $90 \%$, yield an age of $540 \pm 5 \mathrm{Ma}$ with a 

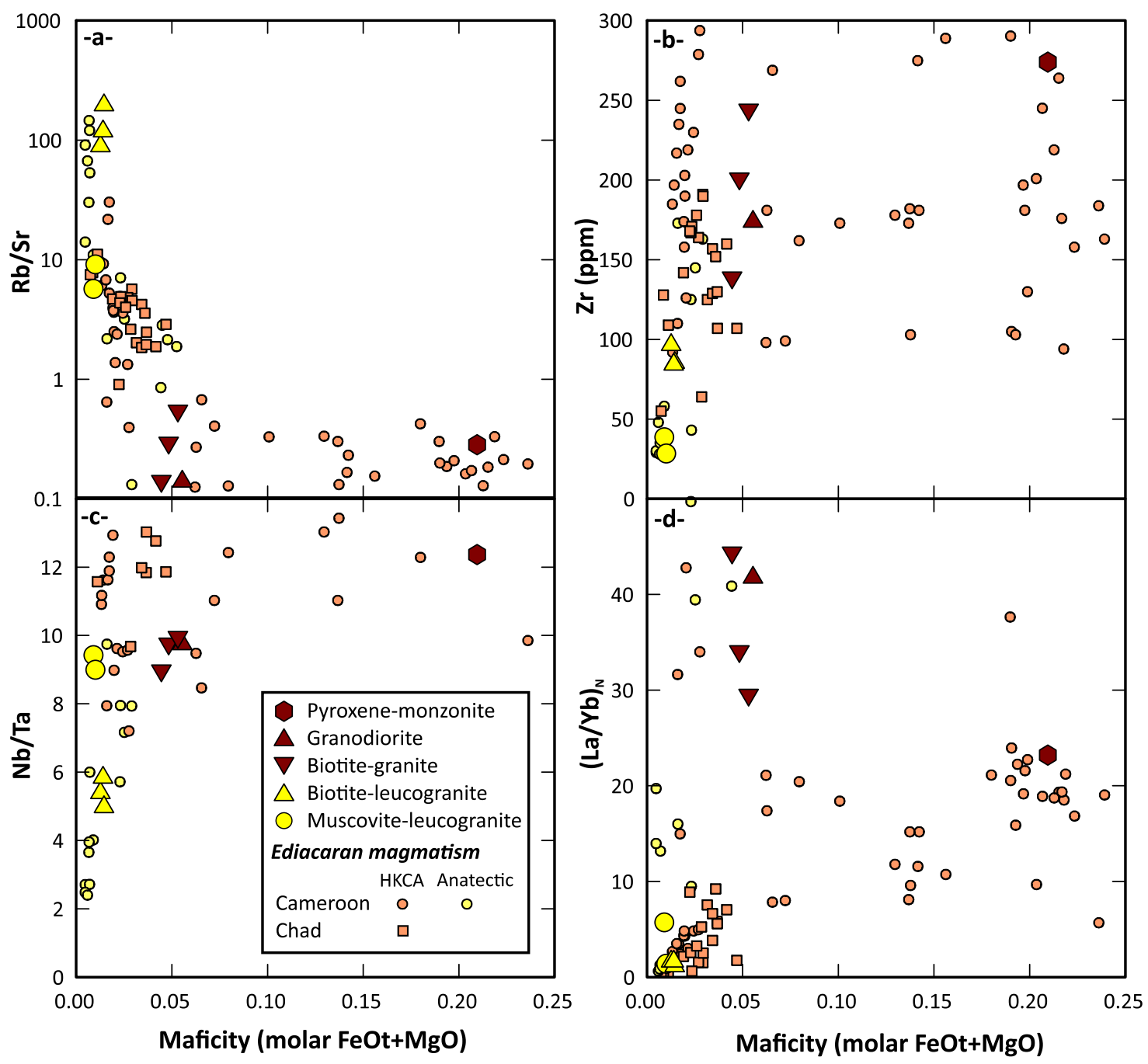

Fig. 7. Plots of maficity versus (a) Rb/Sr ratio; (b) $\mathrm{Zr}$ (in ppm); (c) $\mathrm{Nb} / \mathrm{Ta}$ ratio and (d) normalized La/Yb ratio ratios. Note the low maficity of leucogranite compared to high-K granodiorite and granite and the very evolved nature of biotite leucogranites with their high $\mathrm{Rb}$ contents and low $\mathrm{Nb} / \mathrm{Ta}$ ratios. See text for data sources on $\mathrm{COAfB}$ occurrences.

MSWD of 0.33 . Considering they emplaced after the regional Pan-African deformation event, the oldest ages most probably represent inherited cores while the lowermost Cambrian age reflects igneous crystallization. A late Ediacaran igneous activity is known in the CAfOB and especially in the neighboring Guera Massif(Shellnutt et al., 2019) where inherited $\sim 1$ Ga cores have also been found (Shellnutt et al., 2017).

\section{Geochemistry and $\mathrm{Nd}$ isotopic composition}

The geochemical characteristics of the different metaplutonic and plutonic rocks of the southern Ouaddaï are illustrated first in binaryl major and trace element diagrams (Figs. 6 and 7) and then in multi-element and REE diagrams (Figs. 8 and 9). These diagrams allow identifying the main magmatic trends and are compared to the $\mathrm{Nd}$ isotopic signature of the different facies (Tabs. 5 and 6).

Amphibolite samples GB15-24A and GB15-24AB have the composition of cumulate gabbroic rocks as revealed by their high $\mathrm{Al}$ and $\mathrm{Ca}$ content (16.6-21.0 $\mathrm{Al}_{2} \mathrm{O}_{3} \mathrm{wt} \%$ and $13.1-$ $14.1 \mathrm{wt} \% \mathrm{CaO})$, high molar Mg\# (72), high $\mathrm{Cr}$ (920-940 ppm) and low content in most incompatible elements (4.9-7.5 ppm $\mathrm{Zr}$; 1.1-1.5 ppm Ce; 1 ppm Th) except for $\mathrm{Sr}(120-210 \mathrm{ppm})$ (Tab. 5). They are depleted in LREE $\left((\mathrm{La} / \mathrm{Yb})_{\mathrm{N}}: \sim 0.7\right)$ with a positive Eu anomaly (Eu/Eu*: 1.95), the latter being consistent with the accumulation of plagioclase in the igneous precursors (Fig. 8a). The multi-element plot shows peaks for $\mathrm{Ba}, \mathrm{Pb}$ and Sr but very low contents in other trace elements (Fig. 9a). The $\mathrm{Nd} \mathrm{T}_{\mathrm{DM}}$ model age of amphibolites cannot be calculated because the $\mathrm{Sm} / \mathrm{Nd}$ ratio is close to the one of depleted mantle (Tab. 6). However, the initial ${ }^{143} \mathrm{Nd} /{ }^{144} \mathrm{Nd}$ is positive at $1000 \mathrm{Ma}(+1.8$ and +2.6$), 700 \mathrm{Ma}(+3.4$ and +3.5$)$ and $600 \mathrm{Ma}(+3.7$ and +4.1$)$ suggesting their parental magma derived from a depleted mantle source.

Biotite-leucogranite samples (GB16-5, GB16-25A, GB16-25B) are silica-rich $\left(\sim 76 \mathrm{wt} \% \mathrm{SiO}_{2}\right)$ with very low contents in $\mathrm{MgO}(<0.06 \mathrm{wt} \%), \mathrm{TiO}_{2}$ and $\mathrm{P}_{2} \mathrm{O}_{5}(<0.03 \mathrm{wt} \%)$ and with about $1 \mathrm{wt} \% \mathrm{Fe}_{2} \mathrm{O}_{3 \mathrm{t}}$. They are peraluminous (molar A/CNK: $1.05-1.11$ ) (Figs. $6 \mathrm{~b}$ and $6 \mathrm{c}$ ) but also show high $\mathrm{K}$ 
Table 4. Results of U-Pb dating on the biotite granite (GB15-20A).

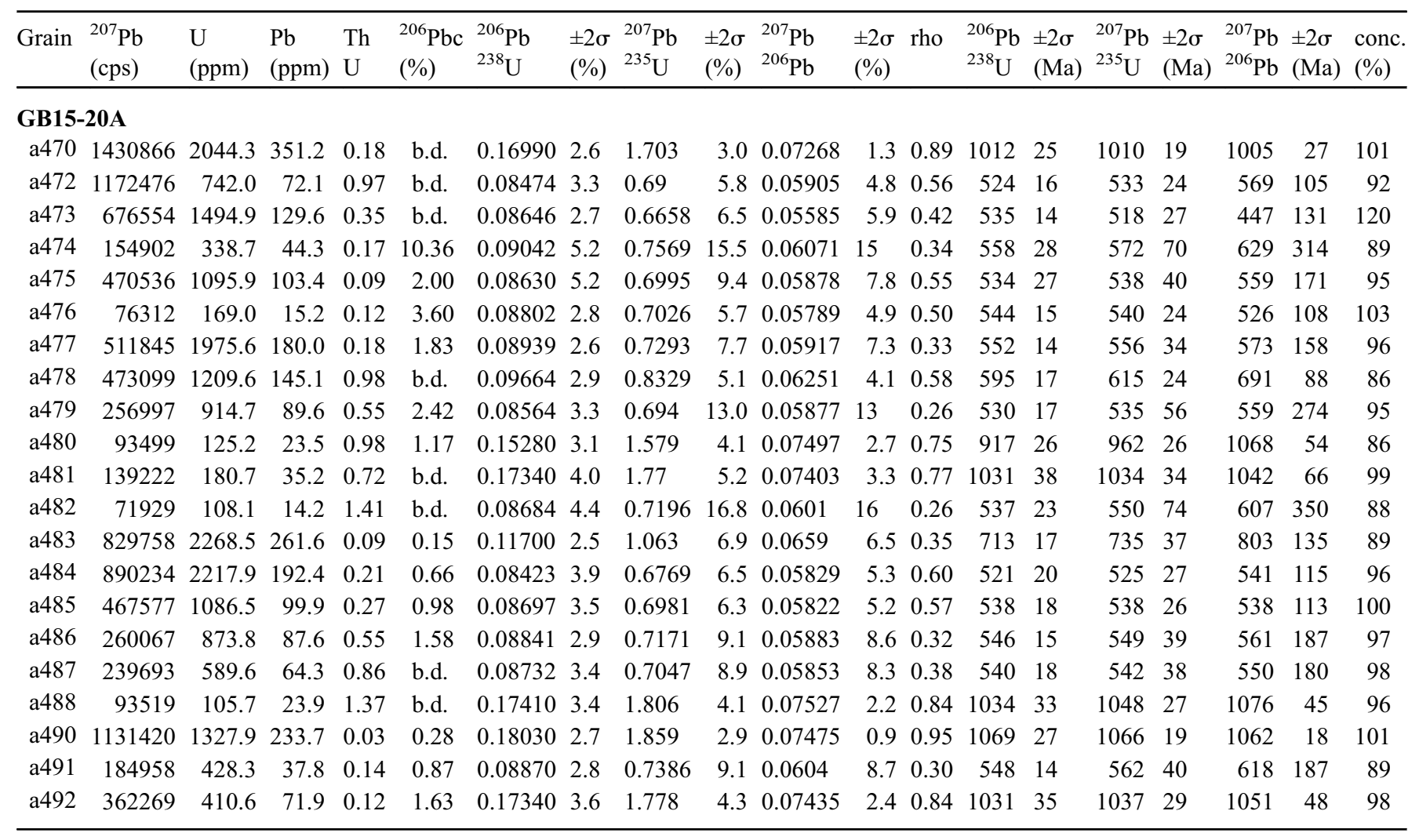

compositions $\left(\mathrm{K}_{2} \mathrm{O}: 4.43-4.58 \mathrm{wt} \%\right)$. $\mathrm{Rb}$ contents are high (710-790 ppm), yielding high $\mathrm{Rb} / \mathrm{Sr}$ ratios (89-196), compared to other plutonic rocks from the southern Ouaddaï Massif and the whole CAfOB (Fig. 7a). They display geochemical features of highly evolved granites (NK/A: 0.90-0.94) with high contents in incompatible elements such as $\mathrm{Nb}(41-49 \mathrm{ppm})$, Th (33-37 ppm) and U (14-20 ppm) but low concentration in plagioclase-compatible elements $(\mathrm{Ba}, \mathrm{Sr}$ and $\mathrm{Eu})$. The REE pattern is very different from the previously described samples. It shows lower LREE contents but higher HREE values yielding a flat pattern $\left((\mathrm{La} / \mathrm{Yb})_{\mathrm{N}}\right.$ : 1.14-1.62) with a deep negative Eu anomaly (Eu/Eu*: 0.0120.021 ; Fig. 8c). The multi-element plot also displays a positive peak for $\mathrm{Pb}$ and decreasing normalized abundances from most to less incompatible elements (from left to right). There is no pronounced negative anomaly in $\mathrm{Nb}$ but a slight positive spike in Ta leading to fractionated $\mathrm{Nb} / \mathrm{Ta}$ ratios $(5.0-$ 5.8; Fig. 7c) compared to the bulk upper continental crust value (13; Rudnick and Gao, 1995). Initial $\varepsilon N d$ has been determined on one sample and yields -18.2 . The $\mathrm{T}_{\mathrm{DM}}$ model age cannot be calculated as the ${ }^{147} \mathrm{Sm} /{ }^{144} \mathrm{Nd}$ ratio of sample GB16-5 (0.236) is close to the average depleted mantle value (Tab. 6).

Muscovite-leucogranite samples (GB16-3B, GB15-12) are also silica-rich $\left(74.5-75.7 \mathrm{wt} \% \mathrm{SiO}_{2}\right)$ with low contents in $\mathrm{Fe}_{2} \mathrm{O}_{3 \mathrm{t}}(0.64-0.67)$ and very low concentrations in $\mathrm{MgO}, \mathrm{TiO}_{2}$, $\mathrm{P}_{2} \mathrm{O}_{5}$ (close or below detection limits). They are peraluminous (molar A/CNK: 1.05-1.15) and, according to their mineralogical characteristics, belong to evolved S-type granites (Fig. 6c) with NK/A ranging between 0.80 and 0.85 . They have very low REE contents compared to other Ouaddaï samples with either a concave upward, HREE-rich pattern (garnet-bearing leucogranite GB16-3B) or a LREE-enriched pattern with a (La/ $\mathrm{Yb})_{\mathrm{N}}$ ratio of 5.7. The multi-element plot is characterized by very low contents in $\mathrm{Ba}$, LREE, $\mathrm{Zr}-\mathrm{Hf}$ and $\mathrm{Sr}$ but similar trends for elements ranging from $\mathrm{Rb}$ to $\mathrm{Ta}$ compared to the monzonitegranodiorite-biotite granite suite. There is a negative anomaly for $\mathrm{Nb}$ and a positive one for $\mathrm{Pb}$ (Fig. 9d). $\mathrm{Nd}$ isotope composition measured on two samples yield $\varepsilon \mathrm{Nd}_{(620 \mathrm{Ma})}$ of -10.2 and -2.2 . The $\mathrm{T}_{\mathrm{DM}}$ model ages are 4195 and $1583 \mathrm{Ma}$, respectively (Tab. 6).

Granodiorite and biotite-granite samples (sample GB15-13, GB16-19A, GB15-20A, GB16-24) display variable high $\mathrm{SiO}_{2}$ (68 to $72 \mathrm{wt} \%$ ) negatively correlated to $\mathrm{MgO}$ content

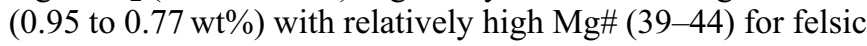
rocks (Fig. 6a). This suite of samples also follows the trend of high-K calc-alkaline series $\left(\mathrm{K}_{2} \mathrm{O}: 3.63-4.79 \mathrm{wt} \%\right)$ and are metaluminous to slightly peraluminous (molar $\mathrm{A} / \mathrm{CNK}$ ranging between 0.94 and 1.02, typical of I-type granitoïds; Figs. 6b and $6 \mathrm{c}$ ). They show rather high maficity (molar $\mathrm{FeO}+\mathrm{MgO}$ : 0.04-0.06; Figs. 7a-7d) and moderate $\mathrm{P}_{2} \mathrm{O}_{5}(0.12-0.21 \mathrm{wt} \%)$. The different samples display very similar REE patterns with strongly enriched LREE normalized abundances compared to $\operatorname{HREE}\left((\mathrm{La} / \mathrm{Yb})_{\mathrm{N}}\right.$ : 29-44), a weak negative to no Eu anomaly $\left(\mathrm{Eu} / \mathrm{Eu}^{*}:\right.$ 0.77-1.05) and a flat pattern for the heaviest REE from Er to Lu (Fig. 8b). The trace-elements plot (Fig. 9b) displays typical features of calc-alkaline subduction-related and of post-collisional igneous rocks, that are (i) higher contents in large-ion lithophile elements (LILE: Rb, Ba, Sr) compared to most HFSE, (ii) enrichment in very incompatible 


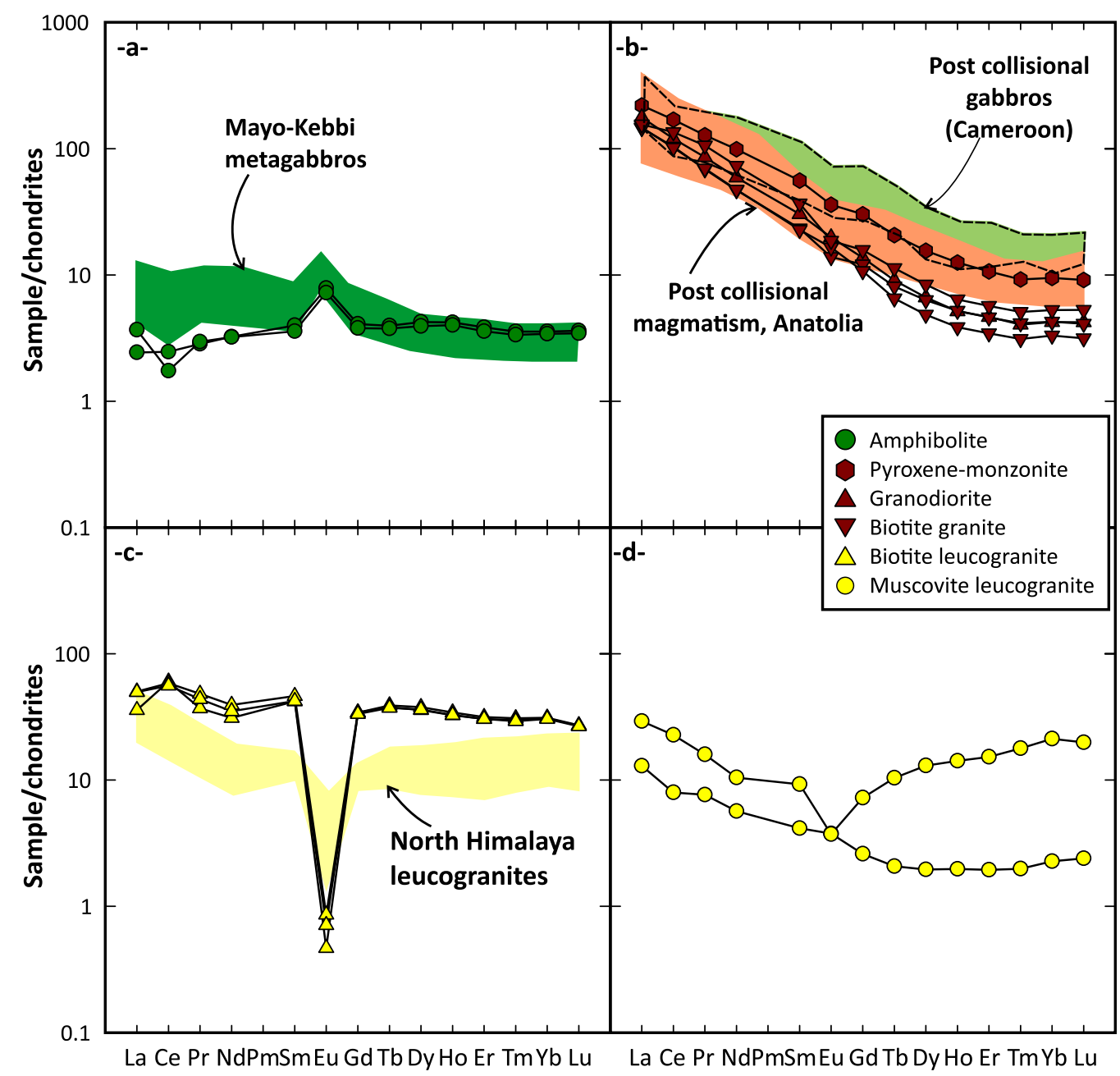

Fig. 8. Chondrite-normalized REE patterns for the magmatic rocks from southern Ouaddaï. The normalizing values are from McDonough et Sun, 1995. (a) Amphibolites compared to metagabbro of Mayo Kebbi (Isseini, 2011). (b) HKCA granitoids (granodiorite-biotite granite and pyroxene monzonite) compared to the post-collisional gabbros from Cameroon (Kwékam et al., 2013) and typical representative post collisional high-K igneous rocks from Anatolia (Dilek and Altunkaynak, 2007). (c) Biotite/muscovite leucogranite compared to the north Himalayan leucogranites (Liu et al., 2016). (d) Muscovite leucogranites.

elements $\left((\mathrm{Th} / \mathrm{Yb})_{\mathrm{N}}\right.$ ratios between 74 and 215$)$ (iii) pronounced negative anomalies for $\mathrm{Nb}$ and Ta relatively to $\mathrm{La}$ and $\mathrm{Th}\left((\mathrm{Th} / \mathrm{Nb})_{\mathrm{N}}\right.$ : $\left.15-29\right)$, (iv) positive spikes for $\mathrm{Pb}$ and (v) very low HREE and Y contents (1 to 4 times primitive mantle values). Samples from this group have $\varepsilon \mathrm{Nd}_{(540 \mathrm{Ma})}$ values ranging from -4.6 to -14.8 and $\mathrm{T}_{\mathrm{DM}}$ model ages between 1300 and $2000 \mathrm{Ma}$ using the depleted mantle evolution of Nelson and DePaolo (1984) (Tab. 6).

The pyroxene-monzonite (GB16-35) has a high molar $\mathrm{Mg} \#$ (59), an intermediate $\mathrm{SiO}_{2}$ content (58.12 wt\%), high $\mathrm{Cr}$ and $\mathrm{Ni}$ contents (330 and $125 \mathrm{ppm}$, respectively) and a high maficity (molar FeO + MgO: 0.21; Figs. 7a-7d), features typical of high Mg\# andesites (Kelemen, 1995). It displays a shoshonitic affinity $\left(\mathrm{K}_{2} \mathrm{O}: 5.57 \mathrm{wt} \%\right)$ and plots in the metaluminous field of the A/NK vs. A/CNK diagram (Fig. 6c). LREE are strongly enriched compared to HREE $\left((\mathrm{La} / \mathrm{Yb})_{\mathrm{N}}\right.$ : 23$)$ with normalized abundances for $\mathrm{La}$ around 200 (Fig. 8b). The multi-element plot shows decreasing abundance from most incompatible to less incompatible elements with pronounced negative $\mathrm{Nb}$ - $\mathrm{Ta}$ anomalies and a positive spike for $\mathrm{Pb}$ (Fig. 9b). This pattern is strikingly similar to those of the high- $\mathrm{K}$ calc-alkaline granodiorite and biotite-granite described above, pointing to a single igneous suite. The $\mathrm{Nd}$ isotopic signature $\left(\varepsilon \mathrm{Nd}_{(540 \mathrm{Ma})}\right.$ : -11.8 ) is within the range of values for granodiorite and biotitegranite and the $\mathrm{Nd}_{\mathrm{DM}}$ model age of $1.9 \mathrm{Ga}$.

\section{Discussion}

\subsection{Age of igneous events in southern Ouaddaï and the significance of inherited zircons}

The Ouaddai was considered by some authors as a piece of pre-Neoproterozoic crust reworked during the Neoproterozoic Pan-African event (Abdelsalam et al., 2002; Liégeois et al., 2013), as Paleoproterozoic basement (Penaye et al., 2006) or as a segment of Neoproterozoic juvenile crust tectonically accreted during the Pan-African orogeny (see Toteu et al., 2004). These contrasting suggestions are here discussed in the light of the first geochronological data obtained on plutonic rocks of the southern Ouaddaï presented in this paper. 


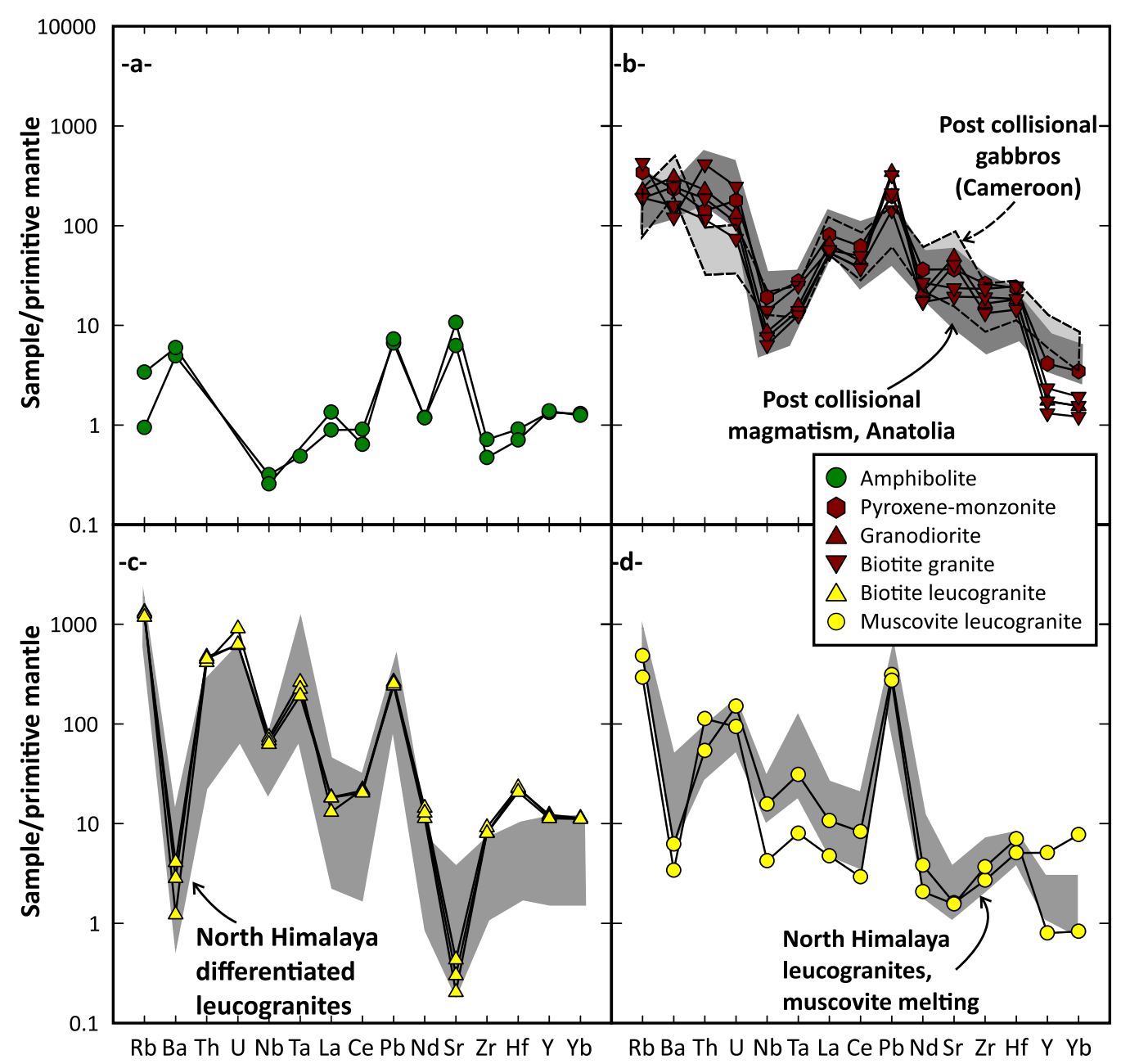

Fig. 9. Multi-element plots using normalization values of McDonough and Sun (1995). (a) Amphibolites. (b) HKCA granitoids (granodioritebiotite granite and pyroxene monzonite) compared to post collisional gabbros from Cameroon (Kwékam et al., 2013) and representative post collisional high-K igneous rocks from Anatolia (Dilek and Altunkaynak, 2007). (c) Biotite/muscovite leucogranite compared to fractionated Himalaya leucogranites (Liu et al., 2016). (d) Muscovite leucogranites compared to north Nimalaya leucogranites formed after muscovite dehydration melting (type A in Gao et al., 2017).

Our results show that intrusive plutonic rocks of the Ouaddai are Ediacaran to lowermost Cambrian, implying that the deposition age of host metasedimentary sequences is between $1.0 \mathrm{Ga}$ (age of youngest detrital zircons; Djerossem, 2018) and $635 \mathrm{Ma}$.

A part from the amphibolites, the oldest igneous plutonic rocks correspond to leucogranites dated at $635 \pm 3$ Ma for the biotite leucogranite and at $613 \pm 8 \mathrm{Ma}$ for the muscovite leucogranite (Fig. 5). Similar Ediacaran igneous ages were obtained for granitic leucosomes and leucogranitic orthogneiss (Figs. 1, 10 and 11) in Western Cameroon (638-608 Ma; Njiekak et al., 2008; Li et al., 2017), in migmatite and leucogranites from North Cameroon (632-603 Ma; Nomo et al., 2017; Fosso Tchunte et al., 2018), in migmatitic paragneisses from Central Cameroon (600-580 Ma; Toteu et al., 2001; Bouyo et al., 2009, 2015; Saha Fouotsa et al., 2019), and also in leucosomes from the East African orogen in Sudan (629-601 Ma; Shang et al., 2010). Following Toteu et al. (2006), the lowermost Ediacaran represents the boundary between active margin calc-alkaline magmatism (before
$626 \mathrm{Ma}$ ) and syn-orogenic crustal anatexis (Figs. 10 and 11). The biotite-leucogranite also contains inherited or partially reset zircons that point to the contribution of rocks containing Archean (upper intercept ages at ca.2600 and ca. $3000 \mathrm{Ma}$ ) and Paleoproterozoic zircons (subconcordant age at ca. $2200 \mathrm{Ma}$ and upper intercept at ca. $2150 \mathrm{Ma}$ ) in the source of these magmas.

The biotite-granite crystallized at $540 \mathrm{Ma}$ (Fig. 5f). This sample has a trace element signature (Figs. $8 \mathrm{~b}$ and $9 \mathrm{~b}$ ) similar to the granodiorite, other biotite-granites and the pyroxenemonzonite, suggesting that they are part of the same igneous suite (see next section) probably emplaced during the same period. Although lowermost Cambrian magmatic rocks have not been recognized yet in the CAfOB, with the exception of detrital alluvial zircons (Shellnutt et al., 2019), Late Ediacaran felsic and basic intrusions characterized by high-K calc-alkaline to shoshonitic affinity down to $545 \mathrm{Ma}$ (Figs. 1, 10 and 11) are commonly found in Cameroon (Djouka-Fonkwé et al., 2008; Kwékam et al., 2013; Bouyo et al., 2015, 2016; Tchouankoue et al., 2016), 
Table 5. Major and trace-element geochemistry of selected samples.

\begin{tabular}{|c|c|c|c|c|c|c|c|c|c|c|c|c|}
\hline & \multicolumn{2}{|c|}{ Amphibolite } & $\begin{array}{l}\text { Px Monzonite } \\
\begin{array}{l}\text { GB16- } \\
35\end{array}\end{array}$ & $\begin{array}{l}\text { Granodiorite } \\
\text { GB15- } \\
13\end{array}$ & \multicolumn{3}{|c|}{ Biotite granite } & \multicolumn{3}{|c|}{ Biotite leucogranite } & \multicolumn{2}{|c|}{ Muscovite leucogranite } \\
\hline \multicolumn{13}{|l|}{$w t \%$} \\
\hline $\mathrm{SiO}_{2}$ & 49.26 & 46.90 & 58.12 & 68.12 & 70.09 & 71.68 & 70.18 & 76.32 & 75.83 & 75.72 & 75.73 & 74.51 \\
\hline $\mathrm{Al}_{2} \mathrm{O}_{3}$ & 21.04 & 16.58 & 14.19 & 15.203 & 14.87 & 13.96 & 14.88 & 12.89 & 12.99 & 12.96 & 13.61 & 14.53 \\
\hline $\mathrm{MgO}$ & 6.49 & 10.82 & 4.91 & 0.95 & 0.76 & 0.82 & 0.77 & $<$ L.D. & $<$ L.D. & 0.06 & 0.05 & 0.07 \\
\hline $\mathrm{CaO}$ & 14.07 & 13.12 & 4.67 & 1.98 & 2.12 & 1.75 & 1.48 & 0.30 & 0.24 & 0.34 & 0.74 & 0.73 \\
\hline $\mathrm{Na}_{2} \mathrm{O}$ & 2.06 & 1.60 & 3.25 & 4.40 & 4.28 & 3.74 & 4.28 & 4.19 & 3.95 & 4.06 & 4.44 & 4.02 \\
\hline $\mathrm{K}_{2} \mathrm{O}$ & 0.06 & 0.16 & 5.57 & 4.60 & 3.63 & 3.95 & 4.79 & 4.46 & 4.43 & 4.58 & 4.03 & 4.59 \\
\hline $\mathrm{TiO}_{2}$ & 3.00 & 0.26 & 0.98 & 0.33 & 0.36 & 0.50 & 0.27 & 0.02 & 0.02 & < L.D. & 0.03 & 0.03 \\
\hline $\mathrm{A} / \mathrm{CNK}$ & 0.72 & 0.62 & 0.71 & 0.96 & 1.00 & 1.03 & 1.00 & 1.05 & 1.11 & 1.06 & 1.045 & 1.13 \\
\hline $\mathrm{Mg \#}$ & 72.03 & 72.50 & 58.67 & 42.89 & 39.65 & 38.77 & 43.54 & & & 10.68 & 12.33 & 17.49 \\
\hline Maficity & 0.22 & 0.37 & 0.21 & 0.05 & 0.05 & 0.05 & 0.04 & 0.13 & 0.13 & 0.01 & 0.01 & 0.01 \\
\hline \multicolumn{13}{|l|}{ ppm } \\
\hline $\mathrm{Sr}$ & 212 & 124 & 726 & 967 & 387 & 469 & 804 & 5.99 & 8.61 & 4.06 & 30.9 & 31.8 \\
\hline $\mathrm{Ba}$ & 32.5 & 39.3 & 1550 & 2036 & 1050 & 801 & 1613 & 27.0 & 18.7 & 8.07 & 22.4 & 41.0 \\
\hline $\mathrm{Rb}$ & 0.57 & 2.0 & 206 & 135 & 114 & 256 & 113 & 710 & 767 & 794 & 176 & 289 \\
\hline $\mathrm{Zr}$ & 7.51 & 4.94 & 273 & 173 & 200 & 244 & 138 & 84.2 & 96.6 & 85.4 & 38.5 & 28.4 \\
\hline $\mathrm{Y}$ & 5.73 & 5.94 & 17.7 & 7.56 & 7.42 & 10.0 & 5.64 & 48.6 & 50.7 & 52.6 & 3.42 & 21.9 \\
\hline Th & < L.D. & <L.D. & 11.2 & 18.1 & 9.16 & 32.8 & 14.8 & 35.7 & 37.4 & 33.1 & 8.9 & 4.29 \\
\hline $\mathrm{U}$ & < L.D. & $<$ L.D. & 4.12 & 2.99 & 1.70 & 5.68 & 2.47 & 14.4 & 14.2 & 20.8 & 2.16 & 3.46 \\
\hline $\mathrm{Nd}$ & 1.48 & 1.47 & 45.3 & 27.0 & 21.4 & 33.4 & 21.6 & 16.0 & 17.9 & 14.1 & 2.59 & 4.77 \\
\hline $\mathrm{Eu}$ & 0.44 & 0.41 & 2.03 & 1.12 & 0.78 & 1.05 & 0.93 & 0.04 & 0.05 & 0.03 & 0.21 & 0.21 \\
\hline $\mathrm{Gd}$ & 0.81 & 0.75 & 6.03 & 2.73 & 2.41 & 3.14 & 2.14 & 6.63 & 6.83 & 6.81 & 0.52 & 1.44 \\
\hline Dy & 1.04 & 0.97 & 3.83 & 1.64 & 1.55 & 2.07 & 1.19 & 8.88 & 8.82 & 9.28 & 0.48 & 3.20 \\
\hline Но & 0.23 & 0.22 & 0.69 & 0.28 & 0.28 & 0.35 & 0.21 & 1.79 & 1.78 & 1.87 & 0.11 & 0.78 \\
\hline $\mathrm{Er}$ & 0.62 & 0.57 & 1.71 & 0.75 & 0.74 & 0.91 & 0.55 & 4.88 & 4.88 & 5.05 & 0.31 & 2.44 \\
\hline $\mathrm{Yb}$ & 0.57 & 0.55 & 1.53 & 0.68 & 0.69 & 0.85 & 0.53 & 4.90 & 4.97 & 5.02 & 0.37 & 3.41 \\
\hline $\mathrm{Lu}$ & 0.09 & 0.09 & 0.22 & 0.10 & 0.10 & 0.13 & 0.08 & 0.66 & 0.66 & 0.67 & 0.06 & 0.49 \\
\hline $\mathrm{Rb} / \mathrm{Sr}$ & 0.00 & 0.01 & 0.28 & 0.14 & 0.29 & 0.55 & 0.14 & 118.58 & 89.11 & 195.86 & 5.68 & 9.09 \\
\hline $\mathrm{Nb} / \mathrm{Ta}$ & 11.55 & & 12.37 & 9.75 & 9.76 & 9.96 & 8.97 & 5.84 & 5.39 & 4.98 & 9.42 & 8.99 \\
\hline$(\mathrm{La} / \mathrm{Yb}) \mathrm{N}$ & 0.68 & 1.08 & 23.21 & 41.77 & 34.06 & 29.51 & 44.38 & 1.63 & 1.15 & 1.63 & 5.70 & 1.38 \\
\hline $\mathrm{Eu} / \mathrm{Eu}^{*}$ & 1.95 & 1.96 & 0.88 & 0.97 & 0.82 & 0.77 & 1.05 & 0.02 & 0.01 & 0.02 & 1.15 & 0.45 \\
\hline $\mathrm{Sr} / \mathrm{Y}$ & 37.07 & 20.96 & 40.97 & 128.24 & 52.21 & 46.67 & 142.67 & 0.12 & 0.17 & 0.08 & 9.05 & 1.45 \\
\hline
\end{tabular}

Chad (Isseini et al., 2012; Shellnutt et al., 2017, 2018, 2019) and Sudan (Küster et al., 2008; Shang et al., 2010). They are interpreted as magmas emplaced during the postcollisional stage of the Pan-African orogeny (see Shellnutt et al., 2019).
Ages of inherited zircons range from 2.1 to $3.0 \mathrm{Ga}$ in the Ediacaran biotite leucogranite and $1.05 \mathrm{Ga}$ in the Early Cambrian biotite granite (Fig. 5). The high $\mathrm{Th} / \mathrm{U}$ ratios of the analyzed zircon grains are consistent with magmatic crystallization. Old zircon cores found in the peraluminous biotite 
Table 6. Sm-Nd isotopic whole-rock data.

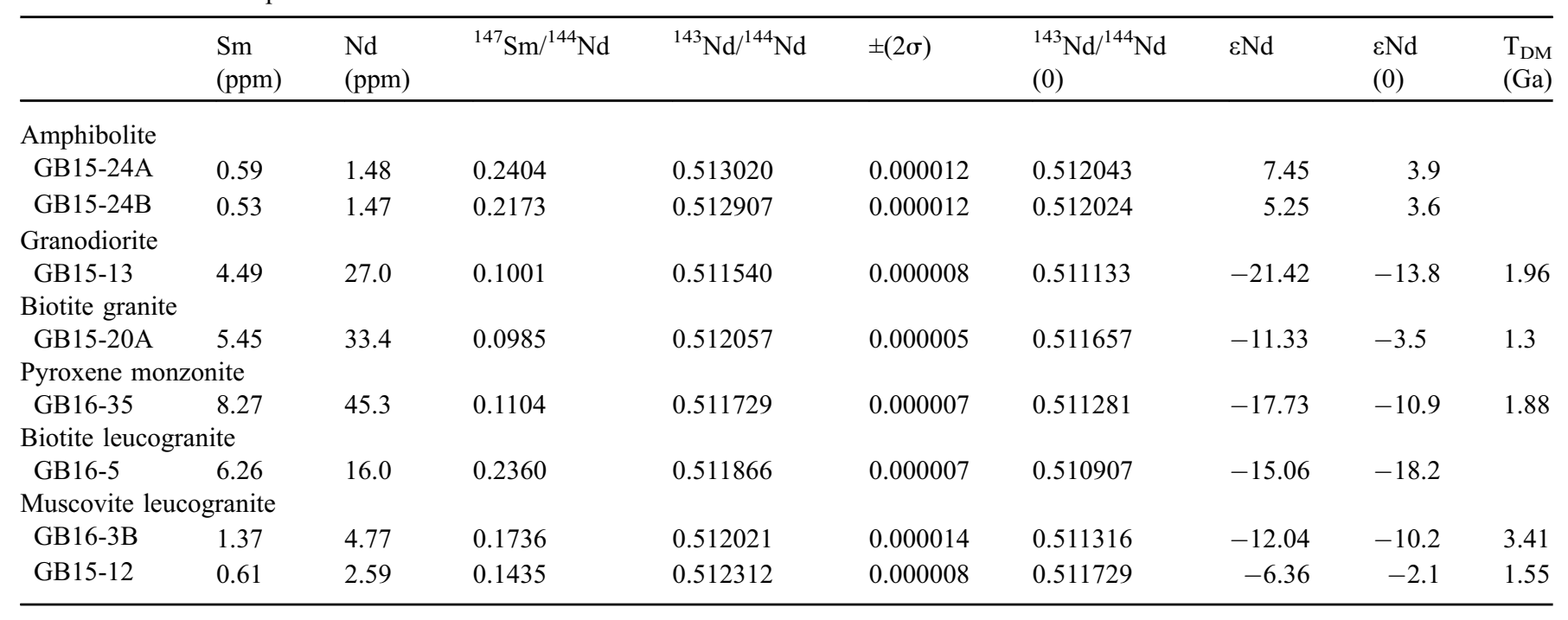

leucogranite (formed after melting of metasediments, see next section) can be derived from post $2.15 \mathrm{Ga}$ basement metasediments forming the source of the leucogranitic magma (see below) in the middle or lower crust. The oldest Archean to Paleoproterozoic ages are common in the Saharan domain and have been interpreted to represent the basement of the Sahara metacraton and surrounding cratons (Abdelsalam et al., 2002). In contrast, Mesoproterozoic zircons found in the biotite granite are rare in Central Africa except as detrital grains or inherited zircons in post collisional magmatic rocks (Meinhold et al., 2011; Shellnutt et al., 2017, 2019) found in the Saharan metacraton domain. Considering the proposed petrogenesis of the Early Cambrian high-K granite biotite (see next section), we suggest that they derive from assimilation of crustal material during differentiation. Occurrences of late Mesoproterozoic igneous rocks have not been discovered yet, but these detrital and inherited zircons in Chad and Lybia definitely indicate that the Saharan metacraton was affected by an igneous event around $1.0 \mathrm{Ga}$, although the nature and context of this magmatism remain elusive.

\subsection{Petrogenesis and significance of the three (meta-) igneous suites}

The geochemical characteristics of amphibolites (high Al and $\mathrm{Mg}$ contents, low REE with positive Eu anomalies; Figs. 6, 7,8 a) sampled in the southern Ouaddaï and described above indicate that they derive from cumulate gabbros. This implies that the geochemical fingerprint of the parental magma has been blurred by fractional crystallization, involving accumulation of plagioclase and/or ferromagnesian silicates. The isotopic signature indicates either a depleted mantle source if the igneous protolith is Neoproterozoic $(\varepsilon N d$ at $600 \mathrm{Ma}:+3$ to $+4)$ and a slightly enriched source or a contaminated mantle derived magma if the igneous event is Paleoproterozoic $(\varepsilon \mathrm{Nd}$ at $2.0 \mathrm{Ga}:-1$ to -4$)$. In the absence of a radiometric age for the mafic igneous rocks precursor to these amphibolites and considering that the geochemical signature does not represent the composition of a melt, no precise information can be extracted on the source and the tectonic context.
Leucogranites are the most abundant magmatic rocks in southern Ouaddaï forming large plutons (Fig. 2b). They are subdivided into biotite-leucogranite and muscovite-leucogranite. The latter have the characteristics of evolved peraluminous S-type granitoids (Chappell and White, 1974; Chappell, 1999) most often formed by partial melting of terrigenous meta-sedimentary sources (Patino Douce, 1999; Clemens and Stevens, 2012). They display low maficity (0.620.67 ) and $\mathrm{P}_{2} \mathrm{O}_{5}$ (below detection limits), high $\mathrm{Al}(13.6-14.5 \mathrm{wt} \%$ $\mathrm{Al}_{2} \mathrm{O}_{3}$ ) compared to biotite leucogranite (Figs. 6 and 7, Tab. 5). Interestingly, $\mathrm{Ba}, \mathrm{Sr}$, LREE and $\mathrm{Zr}$ contents are low (ex: 28$38 \mathrm{ppm} \mathrm{Zr}$ ) while $\mathrm{U}, \mathrm{Th}, \mathrm{Nb}$ and $\mathrm{Ta}$ reach moderate to high concentrations (Figs. 8d and 9d, Tab. 5) defining a trace-element distribution similar to north Himalaya leucogranites formed by muscovite dehydration melting (Gao et al., 2017). Garnetbearing sample GB16-3B is enriched in HREE and Y (Fig. 8d) reflecting peritectic garnet entrainment in the anatectic melt, a common feature of S-type granites (Stevens et al., 2007). Despite an origin by partial melting of a pelitic metasediment, it contains no inherited zircon. The very low bulk rock $\mathrm{Zr}$ content (below 38 ppm, Tab. 5) suggests that the absence of inherited zircons is not due to zircon dissolution in the peraluminous melt because it would have led to high $\mathrm{Zr}$ content in the melt. The paucity of zircons, related to the low bulk $\mathrm{Zr}$ content, together with the low $\mathrm{Rb} / \mathrm{Sr}$ ratio for these samples are compatible with a limited degree of muscovite dehydration-melting (Inger and Harris, 1993; Gardien et al., 1995; Harris et al., 1995; Gao et al., 2017). Harris et al. (1995) explain the low Zr content and of some other incompatible elements, including $\mathrm{P}$, to the location of the melting site within the source rock (typically around muscovite while zircons are often spatially associated to, or included into biotite in metasediments) and to the small volume of melt produced by fluid absent muscovite melting. Low volumes of melt formed around textural sites where zircons are scarce are unable to entrain zircons in the collected magma. The hypothesis considering these granites as near-solidus, low degree partial melts formed by muscovite dehydration melting is corroborated by their low zircon saturation temperatures ranging from 660 to $680^{\circ} \mathrm{C}$ (Watson and Harrison, 1983). These values, albeit low, are in the range of those determined for melts formed by 


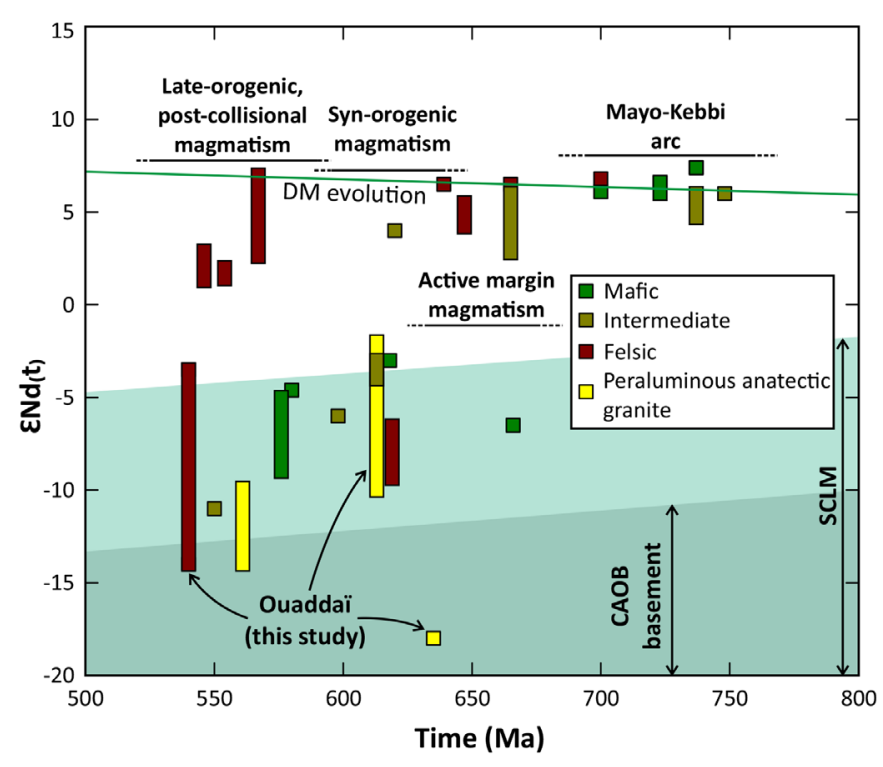

Fig. 10. Compilation of zircon ages and bulk rock epsilon Nd values (acquired on same samples) from Cameroon and Chad. Data from Toteu et al. (2006); Penaye et al. (2006); Djouka-Fonkwé et al. (2008); Kwékam et al. (2010, 2013); Isseini (2011); Isseini et al. (2012); Nkoumbou et al. (2014); Shellnutt et al. (2018). The depleted mantle evolution is calculated as a one stage model with data from Salters and Stracke, 2004). COAB basement evolution is from Toteu et al. (2004). Subcontinental lithospheric mantle evolution has been recalculated with the data of Carlson and Irving (1994) acquired on enriched lherzolite xenoliths representative of the Wyoming craton.

muscovite dehydration-melting (see Harris et al., 1995; Gao et al., 2017) and consistent with the experimental data for muscovite breakdown conditions in the range $670-800^{\circ} \mathrm{C}$ between 5 and $10 \mathrm{kbar}$ (see Vielzeuf and Schmidt, 2001).

Biotite-leucogranite are also peraluminous, silica rich $\left(\sim 76 \mathrm{wt} \% \mathrm{SiO}_{2}\right)$ but show higher $\mathrm{FeO}$ contents $(1.01-1.11 \mathrm{wt}$ $\%)$ and lower alumina $\left(\mathrm{Al}_{2} \mathrm{O}_{3}: 12.9-13.0 \mathrm{wt} \%\right)$ with very low $\mathrm{P}$ and Ti contents (Figs. 6 and 7, Tab. 5). The extremely low contents in plagioclase compatible elements $(\mathrm{Sr}, \mathrm{Ba}, \mathrm{Eu})$ and the strong enrichment in very incompatible elements $(\mathrm{Rb}, \mathrm{Nb}$, $\mathrm{Th}, \mathrm{U}$ ) with the low $\mathrm{Nb} / \mathrm{Ta}$ and $\mathrm{K} / \mathrm{Rb}$ but high $\mathrm{Rb} / \mathrm{Sr}$ ratios is similar to highly fractionated leucogranites from North Himalaya (Liu et al., 2016; Figs. 7, 8c and 9c) and Variscan French Massif central (Williamson et al., 1996). According to experimental data, the $\mathrm{FeO}$ and $\mathrm{Rb}$ contents together with lower $\mathrm{Al}_{2} \mathrm{O}_{3}$ values (compared to muscovite-leucogranite) can be attributed to a partial melting reaction involving biotite in metasediments or, more generally, biotite-bearing metamorphic rocks in the lower crust source (Harris and Inger, 1992). This interpretation is corroborated by the presence of numerous inherited zircons. Both leucogranite types have low initial $\varepsilon N d,-2$ and -10 for muscovite-leucogranite and -18 for the only biotite leucogranite analyzed (Fig. 10), compatible with old radiogenic crustal sources making the basement of the CAfOB (Toteu et al., 2001). Zircon saturation temperatures (Watson and Harris, 1983) are higher for biotite leucogranites $\left(740-750^{\circ} \mathrm{C}\right)$ compared to muscovite leucogranites $\left(660-680^{\circ} \mathrm{C}\right)$, supporting the hypothesis considering they derived from high temperature anatectic melt formed

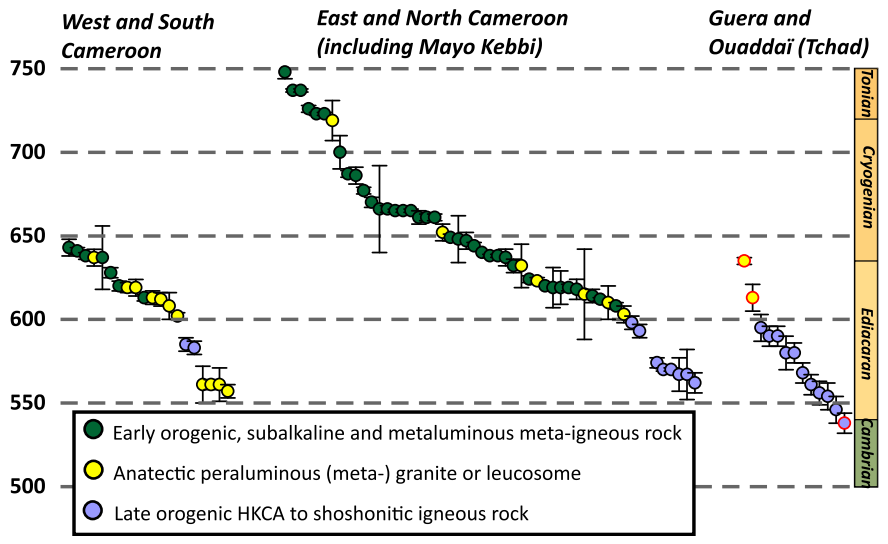

Fig. 11. Compilation of U-Pb (zircon and monazite) ages for igneous events in the Central Africa Orogenic belt in Cameroon and Chad. The data have been subdivided into: (i). early orogenic subalkaline and metaluminous meta-igneous rocks (mainly formed during the subduction-driven magmatic phases and the main orogenic event); (ii). anatectic (meta-) granites and leucosomes; (iii). late orogenic, post collisional rocks with high-K to shoshonitic signatures. Circles with red contour represent data acquired in this study. References are cited in the text.

during biotite dehydration-melting reactions. Temperature required to melt biotite in fluid-absent conditions is in the range $750-850{ }^{\circ} \mathrm{C}$ at a pressure equivalent to lower crustal depths (5-10 kbar; see Vielzeuf and Schmidt, 2001). Such temperatures in the crust during Early Ediacaran suggest a relatively high geothermal gradient (see Vanderhaeghe and Duchêne, 2010).

Granodiorite and biotite-granite form a high-K calcalkaline suite and belong to I-type metaluminous granitoids (Chappell and White, 1974; Chappell, 1999; Clemens and Stevens, 2012). Despite its peculiar major element composition (high $\mathrm{Mg \#}$ and high-K), the shoshonitic pyroxenemonzonite, emplaced at $540 \mathrm{Ma}$, is interpreted to belong to the high-K calc-alkaline suite based on its trace-element signatures (Figs. $8 \mathrm{~b}$ and $9 \mathrm{~b}$ ). The origin of I-type high-K intermediate to felsic magmas is attributed either to (i) partial melting of K-rich basic to intermediate rocks in the crust with entrainment of mafic peritectic minerals (Roberts and Clemens, 1993; Clemens et al., 2011) or (ii) partial melting of a fertile enriched mantle containing phlogopite and/or amphibole producing basic to intermediate high-K magma (Conceicao and Green, 2004; Condamine and Médard, 2014), which can further evolve to silicic compositions after fractional crystallization and assimilation (Castro, 2014). High maficity and high Mg\# (59-39; Fig. 6a) found for this suite favors a mantle origin for the parental magma. Indeed, the most primitive pyroxene monzonite has a high-Mg\# andesitic composition that is generally interpreted to derive from enriched mantle melts with or without crystal fractionation (Kelemen, 1995, Conceicao and Green, 2004). This is consistent with experimental melting of phlogopite and amphibole lherzolite at uppermost mantle conditions (Foley et al., 1987; Condamines and Médard, 2014) that produces high-K to shoshonitic $\left(3-5 \mathrm{wt} \% \mathrm{~K}_{2} \mathrm{O}\right)$ melts with basic to intermediate $\mathrm{SiO}_{2}$ contents ( 52 to $63 \mathrm{wt} \%$ on anhydrous basis). 
All the samples from this suite have unradiogenic $\mathrm{Nd}$ signatures $(\varepsilon \mathrm{Nd}$ : -5 to -14$)$ with $\mathrm{T}_{\mathrm{DM}}$ model ages ranging from 1.3 to $2.0 \mathrm{Ga}$. Such values can be interpreted as tracing (Fig. 10): (i) a crustal source, (ii) an old enriched mantle source such as a subcontinental lithospheric mantle (SCLM) or (iii) a suprasubduction mantle wedge formed during Late Cryogenian and reactivated during the post-collisional period, or (iv) mixing between crustal and mantle-derived magmas. The first hypothesis can be discarded as the suite includes high-Mg\# rocks that necessarily derive from mantle melts. For example, a cratonic SCLM formed in the Archean or in the Paleoproterozoic can evolve toward very negative $\varepsilon N d$ values at $540 \mathrm{Ma}$ (Fig. 10; Carlson and Irving, 1994). Mixing of crustal and mantle components in the mantle (for example during Pan-African subduction) or assimilation of crustal rocks by mantle-derived magmas are also possible but it is difficult to test this hypothesis in absence of data on presubduction mantle, Neoproterozoic pelagic sediments from the Central Africa Orogenic Belt and basement rocks in Ouaddaï. Nevertheless, the presence of inherited $1.05 \mathrm{Ga}$ zircons in the biotite granite suggest that parental magmas have assimilated crustal material but there is not enough isotopic data on this area (and especially on 1.05 Ga rocks that have yet to be found) to quantify crustal assimilation with mixing equations. However, the sample with the lowest $\varepsilon N d$ $(-14)$ is also the one with low Th $(18 \mathrm{ppm})$ compared to the most radiogenic sample ( $\varepsilon N d:-3$, Th: $32 \mathrm{ppm}$ ) while assimilation of crustal material with low $\varepsilon N d$ and high incompatible element content should increase the traceelement content while decreasing $\varepsilon \mathrm{Nd}$ values in the mélange (DePaolo, 1981). Crustal assimilation can therefore not fully explain the trace-element variations in the high- $\mathrm{K}$ to shoshonitic igneous suite. Despite variable silica contents (58-72 wt\%), the Early Cambrian suite display limited traceelement variations (Figs. 8b and 9b) except for $\mathrm{Sr} / \mathrm{Y}(40-140$, Tab. 5) and La/Yb ratios (23-44; Fig. 8b). Crystal fractionation at high pressure $(>1 \mathrm{GPa})$ stabilizes garnet over plagioclase (Sisson and Grove, 1993; Müntener et al., 2001; Alonso-Perez et al., 2009) and lead to magma with high $\mathrm{Sr} / \mathrm{Y}$ and high $\mathrm{La} / \mathrm{Yb}$ ratios (MacPherson et al., 2006; Profeta et al., 2015) with no or little Eu anomaly (Fig. 8b). Garnet fractionation, as deduced from the variations in $\mathrm{Sr} / \mathrm{Y}$ ratios, suggest that high- $\mathrm{K}$ and shoshonitic magma fractionated in the deep levels of a rather thick crust (probably $>30 \mathrm{~km}$; Chiarada, 2015). To sum up, we propose that Early Cambrian high-K to shoshonitic suite of Ouaddaï was formed after partial melting of an enriched and heterogeneous K-rich mantle followed by high pressure fractional crystallization in the deep crust with minor impact of crust assimilation before final emplacement in the supracrustal metasediments. Such a scheme is often proposed for I-type intermediate to felsic plutonic rocks (Castro, 2014) in post collisional context (Dilek and Altunkaynak, 2007).

\subsection{The place of Ouaddaï in the Pan-African belts of Western Gondwana}

The southern Ouaddai is located in the prolongation of the boundary between the Western Cameroon and Central Cameroon domains marked by the Tcholliré-Banyo shear zone and by a gravity anomaly at depth (Fig. 1; Poudjom
Djomani et al., 1995; Toteu et al., 2004; Ngako et al., 2008). Petrological, geochemical and geochronological characteristics of magmatic rocks of the southern Ouaddaï presented in this paper provide new insights on the nature of the PanAfrican CAfOB in this region. The thick metasedimentary series deposited between $1 \mathrm{Ga}$ and $635 \mathrm{Ma}$. They were deformed and recrystallized in greenschist to amphibolite facies conditions suggesting inversion of the sedimentary basin during the Pan-African phase. Early Ediacaran leucogranites, formed by dehydration melting of micas, testify for a temperature broadly between 670 and $850^{\circ} \mathrm{C}$ in deep crustal levels and thus for a high geothermal gradient. The absence of HP metamorphic rocks and of an oceanic suture does not favor an active margin context in Ouddaï during Early Ediacaran. Alternatively, such large detrital basins associated with a high geothermal gradient characterize back-arc basins forming tens to hundreds kilometers from the trench (Collins, 2002; Hydmann et al., 2005). Ouaddaï leucogranites could have formed in the hot lower crust of such a continental back arc basin. $750-600 \mathrm{Ma}$ arc magmatism in the CAOfB is evidenced by juvenile mafic and intermediate rocks forming the Mayo Kebbi massif (Fig. 1) interpreted as an island arc (Penaye et al., 2006; Isseini, 2011) and calc-alkaline batholiths associated with exhumed, often migmatitic gneisses and metasediments formed in an Andean-type active margin (Figs. 1, 10 and 11; Toteu et al., 2004; Bouyo et al., 2015, 2016; Nomo et al., 2017; Tchakounté et al., 2017; Saha Fouotsa et al., 2019). Plutons fed by anatectic magmas emplaced during the same period between 640 and $600 \mathrm{Ma}$ and are intrusive in these metamorphic host rocks (Figs. 1, 10 and 11) (Tchameni et al., 2006; Fosso Tchunte et al., 2018; Li et al., 2017; this study). Parallelism between the CryogenianEdiacaran evolution of the CAOfB in Cameroon and the magmatic evolution of southern Ouaddaï massif strongly support that it belongs to the eastern prolongation of the PanAfrican belt, but that it was located in a back arc position far from the trench where the suture zone will be located. Moreover, the presence of old inherited zircons, the unradiogenic signatures of Ediacaran to Cambrian magmatic rocks, the old $\mathrm{Nd}$ model ages and the absence or paucity of juvenile magmas or accreted rocks in Ouaddaï suggest that the Ouaddaï back arc basin formed by rifting and reworking of an older lithosphere that could correspond to the margin of the Saharan metacraton (Liégeois et al., 2013).

Ouaddaï leucogranites are pre- to syn-kinematic bodies emplaced at 635-612 Ma (Fig. 5) while the post collisional group is dated at $540 \mathrm{Ma}$. In the neighboring Guera massif, Shellnutt et al. (2019) places the onset of post collisional magmatism around 590-580 Ma while last magmatic pulses are dated around $545 \mathrm{Ma}$. The main tectono-metamorphic phase occurred between $635 \mathrm{Ma}$ and $590 \mathrm{Ma}$, a period that typically characterize the Pan-African orogenic stage in Cameroon (Figs. 10 and 11; Toteu et al., 2006, Owona et al., 2011; Li et al., 2017; Saha Fouotsa et al., 2019).

Early Cambrian late kinematic high-K calc-alkaline to shoshonitic rocks form the second main magmatic pulse in Ouaddaii. Parental magmas of these plutonic rocks might have tapped either the old enriched subcontinental lithospheric mantle of the Saharan metacraton (Fig. 11) during the post collisional period of the Pan-African orogeny (Figs. 10 and 11) or the suprasubduction mantle previously enriched during the 
Cryogenian subduction(s). Late orogenic, post collisional magmatism is also well expressed in the CAfOB, from 590 to $545 \mathrm{Ma}$ (Penaye et al., 2006; Isseini et al., 2012; Kwékam et al., 2013; Shellnutt et al., 2017, 2018, 2019; Saha Fouotsa et al., 2019; Figs. 1, 10 and 11) and the southern Ouaddaï comprises the youngest traces of this magmatism, dated at $540 \mathrm{Ma}$. The igneous pulses in the southern Ouaddaï are coeval with the emplacement of Ediacaran to Early Cambrian magmas in the central part of the CAfOB in Cameroon (Figs. 1, 10 and 11).

\section{Conclusion}

The first geochronological data on rocks from southern Ouaddaï presented in this work, demonstrate that this massif is composed of Neoproterozoic metasedimentary and igneous rock affected by the Pan-African orogeny. It is located along the eastern termination of the Central Africa Orogenic Belt and on the southern margin of the Saharan metacraton. The clastic metasediments deformed and recrystallized in the greenschist to amphibolite facies during the Ediacaran, and were intruded by several intermediate to felsic plutonic bodies. Large batholiths made of peraluminous leucogranites emplaced between 635 and $612 \mathrm{Ma}$; they formed after melting of metasedimentary rocks in the deep crust during the paroxysmal Pan-African event and correlates with similar evolution in neighboring Precambrian massifs in Cameroon. We suggest that thermal conditions required to melt the deep crust at the Cryogenian/Ediacaran transition were reached in the thinned lithosphere of a continental back arc basin later inverted during the main Pan-African orogenic phase. The leucogranites preserve Archean to Paleoproterozoic zircons probably inherited from the metasedimentary sources in the middle to lower crust. High-K to shoshonitic intermediate and felsic magmatic rocks emplaced at the Ediacaran/Cambrian boundary after partial melting of an enriched mantle with further differentiation in a relatively thick $(>30 \mathrm{~km})$ crust. This enriched mantle could either correspond to the old subcontinental lithospheric mantle belonging to the southern edge of the Saharan metacraton or to an orogenic mantle previously metasomatized by slab-derived fluids and melts. The late Pan-African magmatism of Ouaddaï is coeval with an orogenwide phase of late orogenic post collisional magmatism recorded in Cameroon and Chad, which tapped a heterogeneously enriched mantle underlying the whole Central Africa Orogenic Belt.

These data show that an Archean to Paleoproterozoic metaigneous or metamorphic basement is not cropping out in Ouaddaï, in contrast to what was proposed by some authors. This old basement is however potentially present below the thick supracrustal sequence made of clastic metasediments. Inherited $1.05 \mathrm{Ga}$ zircons in a biotite-granite suggest the contribution from Mesoproterozoic igneous rocks that might represent parts of the unexposed basement under the Early Neoproterozoic metasedimentary sequence. Exploration of U$\mathrm{Pb}$ age and $\varepsilon \mathrm{Hf}$ signatures in detrital zircons would give insight into phases of juvenile, mantle-derived magmatism and crustal reworking from the Archean to the Neoproterozoic in Ouaddaï. Further studies should also emphasize the relative timing between metamorphism, deformation and magmatism to better integrate the Ouaddaï massif within the tectono-metamorphic evolution of the Central Africa Orogenic belt.

Acknowledgements. This work is part of Félix Djerossem PhD thesis conducted at the Université Paul Sabatier, Toulouse 3 with a fellowship from the French Embassy in Chad. This work is part of the URCO project funded by the CNRS-NEEDS Program for field and analytical expenses. Field work benefited from the assistance of Issaka Ousman Al-Gadam and Ahmat Aboulfathi Haroun Djarma. Fabienne de Parseval and JeanFrançois Ména are thanked for the confection of thin sections and Thierry Aigouy for assistance with the SEM. J.-P. Liégeois and R. Schmitt provided constructive reviews; R. Augier and L. Jolivet are acknowledged for their editorial handling.

\section{References}

Abdelsalam MG, Liégeois JP, Stern RJ. 2002. The Saharan Metacraton. Journal of African Earth Sciences 34: 119-136.

Alonso-Perez R, Müntener O, Ulmer P. 2009. Igneous garnet and amphibole fractionation in the roots of island arcs: experimental constraints on andesitic liquids. Contributions to Mineralogy and Petrology 157: 541-558.

Begg GC, Griffin WL, Natapov LM, O’Reilly SY, Grand SP, O’Neill CJ, et al. 2009. The lithospheric architecture of Africa: Seismic tomography, mantle petrology, and tectonic evolution. Geosphere 5: 23 .

Bessoles B, Trompette R. 1980. La chaîne panafricaine. Zone mobile d'Afrique Centrale (partie sud) et zone soudanaise. Mémoire du Bureau de Recherches Géologiques et Minières, Orléans, 92: $394 \mathrm{p}$.

Bertrand JM, Caby R. 1978. Geodynamic evolution of the PanAfrican Orogenic Belt: A new interpretation of the Hoggar Shield (Algerian Sahara). Geologische Rundschau 67: 357-388.

Black R, Liégeois JP. 1993. Cratons, mobile belts, alkaline rocks and continental lithospheric mantle: The Pan-African testimony. Journal of the Geological Society of London 150: 89-98.

Bouyo HM, Toteu SF, Deloule E, Penaye J, Van Schmus WR. 2009. $\mathrm{U}-\mathrm{Pb}$ and $\mathrm{Sm}-\mathrm{Nd}$ dating of high-pressure granulites from Tcholliré and Banyo regions: Evidence for a Pan-African granulite facies metamorphism in north-central Cameroon. Journal of African Earth Sciences 54: 144-154.

Bouyo MH, Zhao Y, Penaye J, Zhang SH, Njel UO. 2015. Neoproterozoic subduction-related metavolcanic and metasedimentary rocks from the Rey Bouba Greenstone Belt of northcentral Cameroon in the Central African Fold Belt: new insights into a continental arc geodynamic setting. Precambrian Research 2: $40-53$

Bouyo MH, Penaye J, Njel UO, Moussango API, Sep JPN, Nyama BA, et al. 2016. Geochronological, geochemical and mineralogical constraints of emplacement depth of TTG suite from the Sinassi Batholith in the Central African Fold Belt (CAFB) of northern Cameroon: implications for tectonomagmatic evolution. Journal of African Earth Sciences 116: 9-41.

Carignan J, Hild P, Mevelle G, Morel J, Yeghicheyan D. 2001. Routine analyses of trace elements in geological samples using flow injection and low pressure on-line liquid chromatography coupled to ICP-MS: A study of geochemical reference materials BR, DR-N, UB-N, AN-G and GH. Geostandards Newsletter 25: 187-198.

Carlson RW, Irving AJ. 1994. Depletion and enrichment history of subcontinental lithospheric mantle: $\mathrm{An} \mathrm{Os}, \mathrm{Sr}, \mathrm{Nd}$ and $\mathrm{Pb}$ isotopic study of ultramafic xenoliths from the northwestern Wyoming Craton. Earth and Planetary Sciences Letters 126: 457-472. 
Castro A. 2014. The off-crust origin of granite batholiths. Geoscience Frontiers 5: 63-75.

Chappell BW, White AJR. 1974. Two contrasting granite types. Pacific Geology 8: 173-174.

Chappell BW. 1999. Aluminium saturation in I- and S-type granites and the characterization of fractionated haplogranites. Lithos 46: 535-551.

Chiarada M. 2015. Crustal thickness control on $\mathrm{Sr} / \mathrm{Y}$ signatures of recent arc magmas: an Earth scale perspective. Scientific Reports 5: 8115.

Clemens JD, Stevens G. 2012. What controls chemical variation in granitic magmas? Lithos 134-135: 317-329.

Clemens JD, Stevens G, Farina F. 2011. The enigmatic sources of Itype granites: The peritectic connexion. Lithos 126: 174-181.

Conceicao RV, Green DH. 2004. Derivation of potassic (shoshinitic) magmas by decompression melting of phlogopite + pargasite lherzolite. Lithos 72: 209-229.

Condamine P, Médard E. 2014. Experimental melting of phlogopitebearing mantle at $1 \mathrm{GPa}$ : Implications for potassic magmatism. Earth and Planetary Science Letters 397: 80-92.

Collins WJ. 2002. Hot orogens, tectonic switching, and creation of continental crust. Geology 30: 535-538.

de Wit MJ, Linol B. 2015. Precambrian basement of the Congo Basin and its flanking terrains. In: Geology and Resource Potential of the Congo. Spinger, pp. 19-37.

DePaolo DJ. 1981. Trace element and isotopic effects of combined wallrock assimilation and fractional crystallization. Earth and Planetary Science Letters 53: 189-202

Dilek Y, Altunkaynak S. 2007. Cenozoic Crustal Evolution and Mantle Dynamics of Post-Collisional Magmatism in Western Anatolia. International Geology Review 49: 431-453.

Djerossem F. 2018. Croissance et remobilisation crustales au PanAfricain dans le sud du massif du Ouaddaï (Tchad). Unpublished PhD Thesis (Avalaible online), Université Paul Sabatier, Toulouse 3, 302 p.

Djouka-Fonkwé ML, Schulz B, Schussler U, Tchouankoue P, Nzolang C. 2008. Geochemistry of the Bafoussam Pan-African I- and S-type granitoids in western Cameroon. Journal of African Earth Sciences 50: 148-167.

Foley SF, Venturelli G, Green DH, Toscani L. 1987. The ultrapotassic rocks: Characteristics, classification, and constraints for petrogenetic models. Earth-Science Reviews 24: 81-134.

Fosso Tchunte PM, Tchameni R, André-Mayer AS, Dakoure SH, Turlin F, Poujol N, et al. 2018. Evidence for Nb-Ta Occurrences in the Syn-Tectonic Pan-African Mayo Salah Leucogranite (Northern Cameroon): Constraints from Nb-Ta Oxide Mineralogy, Geochemistry and U-Pb LA-ICP-MS Geochronology on Columbite and Monazite. Minerals 8: 188.

Frost BR, Barnes CG, Collins WJ, Arculus RJ, Ellis DJ, Frost CD. 2001. A geochemical classification for granitic rocks. Journal of Petrology 42: 2033-2048.

Gardien V, Thompson AB, Grudjic D, Ulmer P. 1995. Experimental melting of biotite + plagioclase + quartz \pm muscovite assemblages and implications for crustal melting. Journal of Geophysical Research: Solid Earth 100: 15581-15591.

Gao LE, Zeng L, Asimow PD. 2017. Contrasting geochemical signatures of fluid-absent versus fluid-fluxed melting of muscovite in metasedimentary sources: The Himalayan leucogranites. Geology 45: 39-42.

Geisler T, Schaltegger U, Tomaschek F. 2007. Re-equilibration of zircon in aqueous fluids and melts. Elements 3: 45-51.

Gerdes A, Zeh A. 2009. Zircon formation versus zircon alterationNew insights from combined U-Pb and Lu-Hf in-situ LA-ICP-MS analyses, and consequences for the interpretation of Archean zircon from the Central Zone of the Limpopo Belt. Chemical Geology 261: 230-243.

Gsell J, Sonnet J. 1960. Carte géologique de reconnaissance au 1/ 500000 et notice explicative sur la feuille Adre. Brazzaville, $B R G M, 42 \mathrm{p}$.

Harris NBW, Inger S. 1992. Trace element modelling of pelitederived granites. Contributions to Mineralogy and Petrology 110: 46-56.

Harris N, Ayres M, Massey J. 1995. Geochemistry of granitic melts produced during the incongruent melting of muscovite: implications for the extraction of Himalayan leucogranite magmas. Journal of Geophysical Research: Solid Earth 100: $15767-15777$.

Hydmann RD, Currie CA, Mazzotti SP. 2005. Subduction zone backarcs, mobile belts and orogenic belt. GSA Today 15: 4-10.

Inger S, Harris N. 1993. Geochemical Constraints on Leucogranite Magmatism in the Langtang Valley, Nepal Himalaya. Journal of Petrology 34: 345-368.

Isseini M. 2011. Croissance et différenciation crustales au Néoprotérozoïque : exemple du domaine panafricain du Mayo-Kebbi au Sud-Ouest du Tchad. Thèse de Doctorat, Université Henri Poincaré, Nancy, France, 339 p.

Isseini M, André-Mayer AS, Vanderhaeghe O, Barbey P, Deloule E. 2012. A-type granites from the Pan-African orogenic belt in southwestern Chad constrained using geochemistry, $\mathrm{Sr}-\mathrm{Nd}$ isotopes and $\mathrm{U}-\mathrm{Pb}$ geochronology. Lithos 153: 39-52.

Jackson SE, Pearson NJ, Griffin WL, Belousova EA. 2004. The application of laser ablation-inductively coupled plasma-mass spectrometry to in situ $\mathrm{U}-\mathrm{Pb}$ zircon geochronology. Chemical Geology 211: 47-69.

Kelemen PB. 1995. Genesis of high $\mathrm{Mg} \#$ andesites and the continental crust. Contributions to Mineralogy and Petrology 120: 1-19.

Kwékam M, Liégeois JP, Njonfang, E, Affaton P, Hartmann G, Tchoua F. 2010. Nature, origin and significance of the Fomopéa Pan-African high-K calc-alkaline plutonic complex in the Central African fold belt (Cameroon). Journal of African Earth Sciences 57: 79-95.

Kwékam M, Affaton P, Bruguier O, Liégeois JP, Hartmann G, Njonfang E. 2013. The Pan-African Kekem gabbro-norite (WestCameroon), $\mathrm{U}-\mathrm{Pb}$ zircon age, geochemistry and $\mathrm{Sr}-\mathrm{Nd}$ isotopes: Geodynamical implication for the evolution of the Central African fold belt. Journal of African Earth Sciences 84: 70-88.

Küster D, Liégeois JP, Matukov D, Sergeev S, Lucassen F. 2008. Zircon geochronology and $\mathrm{Sr}, \mathrm{Nd}, \mathrm{Pb}$ isotope geochemistry of granitoids from Bayuda Desert and Sabaloka (Sudan): evidence for a Bayudian event (920-900 Ma) preceding the Pan-African orogenic cycle (860-590 Ma) at the eastern boundary of the Saharan Metacraton. Precambrian Research 164: 16-39.

Li XH, Chen Y, Tchouankoue JP, Liu CZ, Jiao Li J, Ling XX, et al. 2017. Improving geochronological framework of the Pan-African orogeny in Cameroon: New SIMS zircon and monazite U-Pb age constraints. Precambrian Research 294: 307-321.

Liégeois JP, Abdelsalam MG, Ennih N, Ouabadi A. 2013. Metacraton: Nature, genesis and behavior. Gondwana Research 23: $220-237$.

Liu ZC, Wu FY, Ding L, Liu XC, Wang JG, Ji WQ. 2016. Highly fractionated Late Eocene $(\sim 35 \mathrm{Ma})$ leucogranite in the Xiaru Dome, Tethyan Himalaya, South Tibet. Lithos 240-243: 337-354.

Luais B, Telouk P, Albarede F. 1997. Precise and accurate neodymium isotopic measurements by plasma-source mass spectrometry. Geochimica et Cosmochimica Acta 61: 4847-4854. 
Macpherson C, Dreher S, Thirlwall M. 2006. Adakites without slab melting: High pressure differentiation of island arc magma, Mindanao, the Philippines. Earth and Planetary Science Letters 243: 581-593.

McDonough WF, Sun SS. 1995. The composition of the Earth. Chemical Geology 120: 223-253.

Meinhold G, Morton AC, Fanning CM, Frei D, Howard JP, Phillips RJ, et al. 2011. Evidence from detrital zircons for recycling of Mesoproterozoic and Neoproterozoic crust recorded in Paleozoic and Mesozoic sandstones of southern Libya. Earth and Planetary Science Letters 312: 164-175.

Milesi JP, Feybesse JL, Pinna P, Deschamps Y, Kampunzu H, Muhongo S, et al. 2004. Geology and major ore deposits of Africa. 1/1 000000 geological map. BRGM.

Miniar PD, Piccoli PM. 1989. Tectonic discrimination of granitoids. GSA Bulletin 101: 635-643.

Müntener O, Kelemen PB, Grove TL. 2001. The role of H2O during crystallization of primitive arc magmas under uppermost mantle conditions and genesis of igneous pyroxenites: an experimental study. Contributions to Mineralogy and Petrology 141: 643-658.

Nelson BK, DePaolo DJ. 1984. 1.700-Myr greenstone volcanic successions in Southwestern North America and isotopic evolution of Proterozoic mantle. Nature 312: 143-146.

Ngako V, Affaton P, Njonfang E. 2008. Pan-African tectonics in northwestern Cameroon: implication for the history of western Gondwana. Gondwana Research 14: 509-522.

Njiekak G, Dörr W, Tchouankoue JP, Zulauf G. 2008. U-Pb zircon and microfabric data of (meta) granitoids of western Cameroon: Constraints on the timing of pluton emplacement and deformation in the Pan-African belt of central Africa. Lithos 102: 460-477.

Nkoumbou C, Barbey P, Yonta NC, Paquette JL, Villiéras F. 2014. Pre-collisional geodynamic context of the southern margin of the Pan-African fold belt in Cameroon. Journal of African Earth Sciences 99: 245-260.

Nomo EN, Tchameni R, Vanderhaeghe O, Sun F, Barbey P, Tekoum $\mathrm{L}$, et al. 2017. Structure and LA-ICP-MS zircon U-Pb dating of syntectonic plutons emplaced in the Pan-African Banyo-Tcholliré shear zone (central north Cameroon). Journal of African Earth Sciences 131: 251-271.

Owona S, Schulz B, Ratschbacher L, Ondoa J, Ekodeck G, Tchoua F, et al. 2011. Pan-African metamorphic evolution in the southern Yaounde Group (Oubanguide Complex, Cameroon) as revealed by EMP-monazite dating and thermobarometry of garnet metapelites. Journal of African Earth Sciences 59: 125-139.

Patino Douce AE. 1999. What do experiments tell us about the relative contributions of crust and mantle to the origin of granitic magmas? Geological Society of London, Special Publications 168: $55-75$.

Penaye J, Kröner A, Toteu SF, Van Schmus WR, Doumnang JC. 2006. Evolution of the Mayo Kebbi region as revealed by zircon dating: An early (ca. 740Ma) Pan-African magmatic arc in southwestern Chad. Journal of African Earth Sciences 44: 530-542.

Poudjom Djomani YH, Nnange JM, Diament M, Ebinger J, Fairhead JD. 1995. Effective elastic thickness and crustal thickness variations in west central Africa inferred from gravity data. Journal of Geophysical Research: Solid Earth 100: 22047-22070.

Profeta L, Ducea M, Chapman J, Paterson S, Gonzales S, Kirsch M, et al. 2015. Quantifying crustal thickness over time in magmatic arcs. Scientific Reports 5: 17786.

Rickwood. 1989. Boundary lines within petrologic diagrams which use oxides of major and minor elements. Lithos 22: 247-263.
Roberts M, Clemens J. 1993. Origin of high-potassium, calc-alkaline, I-type granitoids. Geology 21: 825-828.

Rocci G. 1965. Essai d'interprétation de mesures géochronologiques. La structure de l'Ouest Africain. Coll. Int. Géochronol., Nancy. Sci. Terre, X, pp. 461-478.

Saha Fouotsa AN, Vanderhaeghe O, Barbey P, Eglinger A, Tchameni $\mathrm{R}$, Zeh A, et al. 2019. The geologic record of the exhumed root of the Central African Orogenic Belt in the central Cameroon domain (Mbé - Sassa-Mbersi region). Journal of African Earth Sciences 151: 286-314.

Salters VJM, Stracke A. 2004. Composition of the depleted mantle. Geochemistry Geophysics Geosystems Q05B07.

Shang CK, Liégeois JP, Satir M, Frisch W, Nsifa EN. 2010. Late Archean high-K granite geochronology of the northern metacratonic margin of the Archean Congo craton, southern Cameroon: Evidence for Pb-loss due to non-metamorphic causes. Gondwana Research 18: 337-355.

Shellnutt JG, Pham NHT, Denyszyn SW, Yeh MW, Lee TY. 2017. Timing of collisional and post-collisional Pan-African Orogeny silicic magmatism in south-central Chad. Precambrian Research 301: 113-123.

Shellnutt JG, Yeh MW, Lee TY, Iizuka Y, Pham NHT, Yang CC. 2018. The origin of Late Ediacaran post-collisional granites near the Chad Lineament, Saharan Metacraton, South-Central Chad. Lithos 304-307: 450-467.

Shellnutt JG, Yeh MW, Pham NHT, Lee TY. 2019. Cryptic regional magmatism in the Southern Saharan Metacraton at $580 \mathrm{Ma}$ Precambrian Research 332: 105398.

Sisson TW, Grove TL. 1993. Experimental investigations of the role of $\mathrm{H} 2 \mathrm{O}$ in calcalkaline differentiation and subduction zone magmatism. Contributions to Mineralogy and Petrology 113: 143-166.

Sláma J, Košler J, Condon DJ, Crowley JL, Gerdes A, Hanchar JM, et al. 2008. Formation of Igneous Layering in Granodiorite by Gravity Flow: a Field, Microstructure and Geochemical Study of the Tuolumne Intrusive Suite at Sawmill Cabyonn California. Journal of Petrology 49: 2009-2042.

Stacey JS, Kramers JD. 1975. Approximation of terrestrial lead isotope evolution by a two-stage model. Earth and Planetary Science Letters 26: 207-221.

Stern RA, Bodorkos S, Kamo SL, Hickman AH, Corfu F. 2009. Measurement of SIMS instrumental mass fractionation of $\mathrm{Pb}$ isotopes during zircon dating. Geostandards and Geoanalytical Research 33: 145-168.

Stevens G, Villaros A, Moyen JF. 2007. Selective peritectic garnet entrainment as the origin of geochemical diversity in S-type granites. Geology 35: 9-12.

Tchakounté J, Eglinger A, Toteu SF, Zeh A, Nkoumbou C, MvondoOndoa J, et al. 2017. The Adamawa-Yadé domain, a piece of Archaean crust in the Neoproterozoic central African orogenic belt (Bafia area, Cameroon). Precambrian Research 299: 210-229.

Tchameni R, Pouclet A, Penaye J, Ganwa AA, Toteu SF. 2006. Petrography and geochemistry of the Ngaoundéré Pan-African granitoids in Central North Cameroon: Implications for their sources and geological setting. Journal of African Earth Sciences 44: 511-529.

Tchouankoue JP, Li XH, Ngo Belnoun RN, Mouafo J, Ferreira VP. 2016. Timing and tectonic implications of the Pan-African Bangangte syenomonzonite, West Cameroon: Constraints from in-situ zircon U-Pb age and Hf-O isotopes. Journal of African Earth Sciences 124: 94-103.

Toteu SF, Van Schmus WR, Penaye J, Michard A. 2001. New U-Pb and $\mathrm{Sm}-\mathrm{Nd}$ data from north-central Cameroon and its bearing on 
the pre-Pan African history of central Africa. Precambrian Research 108: 45-73.

Toteu SF, Penaye J, Djomani YHP. 2004. Geodynamic evolution of the Pan- African belt in central Africa with special reference to Cameroon. Canadian Journal of Earth Sciences 41: 73-85.

Toteu SF, Fouateu RY, Penaye J, Tchakounte J, Mouangue ACS, Van Schmus WR, et al. 2006. U-Pb dating of plutonic rocks involved in the nappe tectonic in southern Cameroon: consequence for the PanAfrican orogenic evolution of the central African fold belt. Journal of African Earth Sciences 44: 479-493.

Van Osta P. 1991. Prospection dans le secteur de Goz Beida, region Ouaddai (Tchad Oriental). N'Djamena: PNUD I DRGM.

Vanderhaeghe O, Duchêne S. 2010. Crustal-scale mass transfer, geotherm and topography at convergent plate boundaries. Terra Nova 22: 315-323.

Vielzeuf D, Schmidt MW. 2001. Melting relations in hydrous systems revisited: application to metapelites, metagreywackes and metabasalts. Contributions to Mineralogy and Petrology 141: 251-267.
Watson EB, Harrison TM. 1983. Zircon saturation revisited: temperature and composition effects in a variety of crustal magma types. Earth and Planetary Sciences Letters 64: 295-304.

Williamson BJ, Shaw A, Downes H, Thirlwall MF. 1996. Geochemical constraints on the genesis of Hercynian two-mica leucogranites from the Massif Central, France. Chemical Geology 127: $25-42$.

Wolff JP. 1964. Geological map of Chad Republic on scale 1/500 000. $B R G M$, Paris.

Zeh A, Gerdes A. 2012. U-Pb and Hf isotope record of detrital zircons from gold-bearing sediments of the Pietersburg Greenstone Belt (South Africa) Is there a common provenance with the Witwatersrand Basin? Precambrian Research 204-205: 46-56.

Zeh A, Gerdes A. 2014. HFSE-transport and U-Pb-Hf isotope homogenization mediated by Ca-bearing aqueous fluids at $2.04 \mathrm{Ga}$ : constraints from zircon, monazite, and garnet of the Venetia Klippe, Limpopo Belt, South Africa. Geochimica et Cosmochimica Acta 138: $81-100$.

Cite this article as: Djerossem F, Berger J, Vanderhaeghe O, Isseini M, Ganne J, Zeh A. 2020. Neoproterozoic magmatic evolution of the southern Ouaddaï Massif (Chad), BSGF - Earth Sciences Bulletin 191: 34. 